\title{
Hrvatska ekonomija između europske periferije i poluperiferije: nalazi iz povijesti hrvatskih visokotehnoloških poduzeća
}

\author{
Nikola PETROVIĆ (D) \\ Institut za društvena istraživanja u Zagrebu, Hrvatska \\ nikola@idi.hr
}

$\mathrm{U}$ radu se tvrdi da je naglasak u istraživanju stanja hrvatske ekonomije potrebno staviti na historijsku kontingenciju i geopolitički položaj Hrvatske kako bi se nadopunila prevladavajuća objašnjenja koja naglašavaju kulturne, unutarnjopolitičke ili ideološke faktore. Kroz kritičku primjenu teorije modernoga svjetskog sistema te zagovaranja korištenja događajne sociologije i analize ovisnosti o prijeđenom putu istražuje se utjecaj Prvoga i Drugoga svjetskog rata, Rezolucije Informbiroa, nestanka Istočnog bloka te raspada Jugoslavije na razvoj hrvatske ekonomije. Utjecaj geopolitičkih promjena na hrvatsku ekonomiju kao i stvaranje ovisnosti o prijeđenom putu promatran je kroz nastanak i razvoj 19 hrvatskih visokotehnoloških poduzeća (među ostalim PLIVE, Končara, Željezare Sisak, Ericssona Nikole Tesle i Podravke). Provedeno je 20 polustrukturiranih intervjua s akterima hrvatskoga istraživačko-razvojnog sektora te su analizirane službene monografije poduzeća, arhivska građa, kao i drugi izvori o tim poduzećima. Prvi svjetski rat i osnivanje monarhističke Jugoslavije znatno su pridonijeli nastanku hrvatske visokotehnološke industrije, jer je strani kapital zbog pristupa novom tržištu zaštićenom visokim carinama ulagao u stvaranje novih poduzeća. Pripreme za Drugi svjetski rat i sam rat omogućili su rast nekih industrija vezanih uz ratnu ekonomiju. Nakon raskida sa Sovjetskim Savezom specifičan je poluperiferni položaj socijalističke Jugoslavije hrvatskim poduzećima omogućavao brže približavanje jezgri u odnosu na poduzeća iz drugih socijalističkih zemalja Srednje Europe. Nestanak Istočnog bloka i raspad Jugoslavije onemogućavala su analizirana poduzeća u korištenju svoje poluperiferne pozicije upravo u trenutku kad su se događale bitne promjene u svjetskoj ekonomiji, tj. nastanak tehnoglobalizma. No, neka su se analizirana visokotehnološka poduzeća uspjela uključiti u tehnoglobalističke mreže, među ostalim i zbog svoga poluperifernog položaja, ili su nastavile svoj samostalan razvoj.

Ključne riječi: historijska kontingencija, periferija, poluperiferija, Hrvatska, visokotehnološka poduzeća, geopolitika, tehnoglobalizam 


\section{Uvod}

Sukob Tita i Staljina iz 1948. godine nije samo snažno utjecao na društvene, političke i ideološke prilike u Jugoslavije, nego i na one ekonomske. ${ }^{1}$ Primjer izravnog utjecaja tog događaja na ekonomski razvoj bilo je osnivanje Tvornice telefonskih uređaja »Nikola Tesla« krajem 1949. Osnivanje tog poduzeća uslijedilo je nakon Rezolucije Informbiroa i zabrane uvoza telefonske opreme iz zemalja Istočne Europe. ${ }^{2}$ To pokazuje kako određeni geopolitički događaj može postaviti smjer razvoja jedne tvrtke, a čije se reperkusije osjećaju još otad. Taj je geopolitički sukob bio odgovoran za stvaranje više faktora koji su pridonijeli tomu da hrvatska ekonomija sustigne, pa i prestigne, neke od drugih socijalističkih srednjoeuropskih ekonomija.

Snažan ekonomski rast socijalističke Jugoslavije od početka pedesetih godina 20. stoljeća, osim brzom industrijalizacijom i poslijeratnom obnovom koja se odvijala u većini europskih zemlja, bio je uzrokovan i njezinim specifičnim položajem između Istočnog bloka predvođenog Sovjetskim Savezom (SSSR) i Zapadnog bloka predvođenog Sjedinjenim Američkim Državama (SAD). Taj je geopolitički položaj zaslužan za tri faktora koji su utjecali na ubrzani ekonomski rast i modernizaciju. Prvo, ekonomska i vojna pomoć SAD-a nakon sovjetsko-jugoslavenskog sukoba (Lampe, Prickett i Adamovic, 1990; Jakovina 2002; Bogetić 2010). Drugo, nakon nekog vremena Jugoslavija je imala lakši pristup tržištima obaju suprotstavljenih blokova, kao i tržištima nesvrstanih zemalja. Treće, položaj Jugoslavije izvan vojnih blokova davao je posebnu važnost vojsci koja je postala izuzetno značajan društveni te posljedično i ekonomski akter (Benoit, 1978). Ti su faktori pridonijeli najsnažnijem ekonomskom rastu u modernoj hrvatskoj povijesti. U razdoblju od 1950. do 1973. ostvaren je najveći rast hrvatskog bruto društvenog proizvoda (Stipetić, 2012). U svijetu je godišnja stopa rasta BDP-a po stanovniku iznosila 2,91\%, dok je u Hrvatskoj ona iznosila 4,97\% (Stipetić, 2012: 432). Hrvatska je na kraju tog razdoblja prestigla zemlje Srednje Europe koje su 1950. godine imale viši BDP po stanovniku, kao što su Mađarska i Poljska (Stipetić, 2012: 459; Tablica 1), a zaostajala je samo za Čehoslovačkom i Slovenijom. No, rezultati iz 2005. pokazuju da je došlo do ponovnog zaostajanja za zemljama bližima europskoj jezgri.

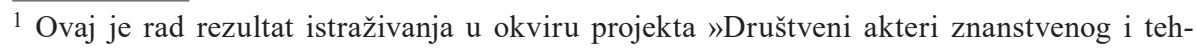
nološkog razvoja« što ga je financiralo Ministarstvo znanosti i obrazovanja.

2 https://www.ericsson.hr/osnutak.
} 
Tablica 1. Vremensko kretanje visine bruto društvenog proizvoda po stanovniku (u USD kupovne snage iz 1990. godine)

\begin{tabular}{ccccccc}
\hline godina & Mađarska & Poljska & Hrvatska & Čehoslovačka & Slovenija & Rumunjska \\
\hline 1913. & 2098 & 1739 & 1376 & 2096 & 2048 & 1741 \\
\hline 1950. & 2480 & 2447 & 1856 & 3501 & 2688 & 1182 \\
\hline 1973. & 5596 & 5340 & 5685 & 7041 & 8698 & 3477 \\
\hline 2005. & 8630 & 8510 & 8100 & $10750 *$ & 15400 & 3940 \\
\hline
\end{tabular}

* Podatak se odnosi samo na Češku.

Izvor: Stipetić, 2012: 459.

Sustizanje iz vremena početka hladnog rata rezultat je ponajprije kontingentnih procesa pozicioniranja unutar globalnih odnosa moći, a manje specifičnosti i uspješnosti jugoslavenske samoupravne ideologije, što upućuje na potrebu analize utjecaja nepredviđenih događaja na ekonomski razvoj. Iako je službeni narativ prikazivao jugoslavenski socijalizam kao rezultat svjesno odabranoga posebnog puta prema ostvarenju socijalističkih ciljeva, »jugoslavensko privredno čudo« dobrim je dijelom rezultat nenamjeravanih posljedica jednog događaja. Sukob Tita i Staljina, dvojice vođa koji su željeli ekspanziju svojih država i ostvarivanje prevlasti na području jugoistočne Europe, odredio je daljnja događanja. Položaj Jugoslavije unutar blokovskih podjela promijenio je i hrvatski položaj unutar relacija europska jezgra, poluperiferija i periferija. To razdoblje dovodi u pitanje povijesni mit koji je Josip Županov nazvao »zla kob Hrvatske kao vječite periferije« (Županov, 1998: 190). On spominje različite kontingentne čimbenike koji utječu na odnos jezgre i periferije kao što su broj stanovnika, veličina unutarnjeg tržišta i stranih investicija, posjedovanje kritičnih resursa poput nafte ili geopolitički položaj i značenje određene zemlje. Svi su ti čimbenici od sredine 19. stoljeća otkad se počinje razvijati moderna hrvatska nacija (Stančić, 2002) bili izuzetno promjenjivi te su mijenjali položaj Hrvatske i njezine ekonomije u modernom svjetskom sistemu.

\section{Teorijski okvir}

I recentnije zaostajanje, tj. vraćanje na početne pozicije u odnosu prema Mađarskoj i Poljskoj može se promatrati kroz analizu historijske kontingencije s kraja osamdesetih godina 20. stoljeća i iz nje proizišle geopolitičke promjene. U radu se tvrdi da je naglasak pri istraživanju stanja hrvatske ekonomije potrebno staviti na historijsku kontingenciju i geopolitički položaj Hrvatske kako bi se nadopunila prevladavajuća objašnjenja koja naglašavaju kultur- 
ne, unutarnjopolitičke ili ideološke faktore. Brojni su razlozi navedeni kao uzroci današnjeg zaostajanja hrvatske za srednjoeuropskim ekonomijama, koji se ugrubo mogu podijeliti na četiri tipa objašnjenja bitna za sociologiju hrvatskog društva. Prema prvom tipu teorija socijalističko nasljeđe, koje je sa sobom nosilo i kulturno nasljeđe agrarnih društava, koči razvoj hrvatske ekonomije i društva (Županov, 1995; Vuković, Štulhofer i Burić, 2017). Drugi tip teorija bavi se tzv. ortačkim kapitalizmom, tj. modelom nacionalnog kapitalizma Hrvatske demokratske zajednice kao uzrokom neuspješne hrvatske tranzicije (Franičević, 2002). Treći tip tumačenja naglašava ponovnu uspostavu kapitalizma i neoliberalizam kao procese koji su zaustavili ekonomski rast i industrijalizaciju (Badovinac, 2004; Mihaljević, 2013). Četvrti tip objašnjenja naglašava da su modernizaciju u Hrvatskoj provodili akteri izvan hrvatskog društva, akteri iz Beča, Pešte i Beograda (Rogić, 2000). Iako neosporno objašnjavaju brojne specifičnosti i probleme hrvatske ekonomije, spomenute se teorije mogu povezati s teleološkim razumijevanjem povijesti, tj. ostvarivanjem meritokratskog i uređenoga liberalnog kapitalizma, samoupravnog socijalizma ili suverene nacionalne države kao ključnih ciljeva povijesti. U ovom se radu postavlja pitanje bi li usmjerenost na historijsku kontingenciju i globalne i regionalne geopolitičke promjene mogla imati veću eksplanatornu snagu u objašnjenju razvoja hrvatske ekonomije. Preciznije rečeno, određeni disruptivni povijesni događaji mogu promijeniti geopolitički i geoekonomski status nekog područja, a time i dugotrajne odnose moći koji su uspostavljeni ranijom industrijalizacijom u drugom području.

Teorija Immanuela Wallersteina o modernom svjetskom sistemu objašnjava odnose između zemalja jezgre, poluperifernih i perifernih zemalja ponajprije kroz podjelu rada unutar svjetske ekonomije, dobrim dijelom oblikovanih procesima kolonizacije i eksploatacije. Počeci modernoga svjetskog sustava razvili su se u 16. stoljeću i kroz podjelu rada u kojem je periferija (Istočna Europa) opskrbljivala sirovinama jezgru (Zapadnu Europu). Srednja Europa se uglavnom nalazila između periferije i jezgre te je Habsburška monarhija bila poluperiferna sila koja nije uspjela imati ekspandirajuću ekonomsku politiku poput zemalja jezgre Engleske i Francuske (Wallerstein, 1986 [1974, 1980]). U vrijeme nastanka modernoga svjetskog sistema, pa sve do 18. stoljeća, hrvatski su krajevi bili mjesto intenzivnih sukoba, migracija i promjena granica (Rogić, 2000).

Wallersteinova teorija proizlazi iz njegova proučavanja problema (de) kolonizacije Afrike i snažnoga marksističkog usmjerenja. Ovdje se pak 
smatra da odnose europske jezgre, periferije i poluperiferije treba promatrati kroz drukčiju prizmu, u kojoj nije riječ isključivo o eksploatacijskom odnosu (Berend i Ránki, 1996). Europski su prostori imali posebnu ulogu unutar odnosa svjetskog sistema i zbog geopolitičkih razloga. Wallerstein kasnije i uzima u obzir geopolitičke promjene nakon Drugoga svjetskog rata i tvrdi kako je Europa postala centar interesa dviju supersila, SAD-a i SSSR-a, gdje promjene nisu bile tolerirane (1991). No, kad se njegova teorija spusti na nižu regionalnu razinu, ona nije dovoljno osjetljiva, jer su se i unutar prostora Srednje i Istočne Europe događali određeni geopolitički pomaci. Wallerstein (1991: 52) spominje brzi ekonomski rast Istočne Europe, no ne analizira intenzivni rast Jugoslavije koji je bio potpomognut geopolitičkom promjenom izlaska Jugoslavije iz Istočnog bloka.

Za ovaj je rad zato bitna kritika Wallersteinove teorije kojoj William H. Sewell (2005) zamjera preveliko oslanjanje na analogiju s astronomijom i teorijom velikog praska. Wallersteinov je pristup, prema Sewellu, suviše deterministički jer tretira društvene sile kao prirodne. Tako je i kolonizacija, u teoriji modernoga svjetskog sistema tretirana kao veliki društveni prasak, dobila snagu zakona i s pomoću nje se još i danas objašnjavaju globalni odnosi. Sewell, pak, stavlja naglasak na globalnu kontingenciju, tj. na nepredviđene događaje koji mogu promijeniti dugotrajne strukture i zalaže se za događajnu sociologiju (eventful sociology). ${ }^{3}$ Jer povijest »pokazuje i tvrdoglave trajnosti i iznenadne prekide, a i najradikalnije povijesne rupture isprepletene su s osobitim kontinuitetima« (Sewell, 2005: 102). Sewell (2005: 228) povijesni događaj definira kao »1) razgranatu sekvencu događanja koju 2) suvremenici prepoznaju kao značajnu i koja 3) rezultira trajnom transformacijom strukture«. Kako su strukture povezane jedna s drugom, ruptura u jednoj strukturi, primjerice u (geo)političkim odnosima moći, može dovesti do ruptura u drugim strukturama, primjerice u ekonomskim i kulturnim. No, jedan događaj, koliko god bio prevratnički, ne uklanja u potpunosti neke povijesno određene i utvrđene strukture. Međutim, on stvara mogućnosti za njihovo prevladavanje, ako se preduvjeti za novu strukturu dovoljno dugo i snažno uspostavljaju, a neki ih novi događaj ne odbaci. U slučaju modernoga svjetskog sistema početni

\footnotetext{
${ }^{3}$ Sewellov poziv na događajnu sociologiju dio je struje u historijskoj sociologiji koja se još od početka osamdesetih godina 20. stoljeća zalaže za snažniju ulogu analize događaja kao pokušaj prevladavanja teleološke i eksperimentalne analize u historijskoj sociologiji (više u Griffin, 1992). Njihova je osnovna ideja da ukoliko sociologija želi imati bolje razumijevanje povijesnih promjena, potreban joj je naglasak na analizi povijesnih događaja.
} 
položaj u tom sistemu utječe na kasniji položaj, no određeni kontingentni događaji i političke promjene mogu promijeniti prijašnje strukturne razlike umanjujući važnost faktora poput industrijske razvijenosti i geografske blizine industrijskoj jezgri.

Iako Wallersteinov moderni svjetski sistem ostaje korisno teorijsko oruđe za razumijevanje globalnih odnosa, potrebno ga je testirati na pojedinačnim slučajevima. U ovom se radu koriste pojmovi jezgre, poluperiferije i periferije, no ti se pojmovi nastoje deideologizirati. Ovdje se ne smatra da su posljedice djelovanja s područja višeg stupnja razvoja isključivo povećanje moći jezgre, nego mogu nenamjeravano i povećavati moć perifernijih krajeva, primjerice potičući njihovu industrijalizaciju, koju nakon političke promjene nova politička elita koristi za svoje potrebe. Također, iako se može govoriti o relativno povezanom svjetskom sistemu, pojmove jezgre, poluperiferije i periferije moguće je analizirati i na europskoj, ali i na razini manjih regija. Tako se položaj Hrvatske u pretpostavljenom svjetskom sustavu treba analizirati kroz izrazito promjenjivo međudjelovanje političkih, ekonomskih i društvenih faktora na europskoj i postsocijalističkoj razini.

Razvoj hrvatske ekonomije analizira se ovdje zato kroz utjecaj nekoliko događaja koji zadovoljavaju Sewellove kriterije i koji su kreirali položaj Hrvatske unutar svjetskih i europskih odnosa, ali i unutar imperijalnih i državnih uređenja u kojima su se krajevi koji danas čine Republiku Hrvatsku nalazili. To su prvo, Prvi svjetski rat, propast Austro-Ugarske i nastanak monarhističke Jugoslavije; drugo, Drugi svjetski rat, nastanak socijalističke Jugoslavije i poslijeratno preslagivanje unutar blokovske podjele svijeta; na kraju nestanak socijalističkog bloka, raspad Jugoslavije i ratovi na području Jugoslavije te uspostava suverene Republike Hrvatske. Značajni povijesni događaji poput ovih imaju snagu stvaranja ovisnosti o prijeđenom putu (path dependence), a koja karakterizira "posebno one povijesne sekvencije u kojima kontingentni događaji pokreću institucionalne okvire ili lance događaja koji imaju determinističke karakteristike« (Mahoney, 2000: 507). James Mahoney nudi snažnu metodološku potporu Sewellovu pozivu na događajnu sociologiju kroz tri ključna uvjeta koja svaka analiza ovisnosti o prijeđenom putu mora sadržavati. ${ }^{4}$ Prvo, »proučavanje kauzalnih procesa

\footnotetext{
${ }^{4}$ Mahoney kao i Sewell, kritizira Wallersteinov pristup povijesti koji on, osim teleološkim, smatra i funkcionalističkim te mu zamjera što ne može objasniti preokrete u sistemu. No, i Mahoney i Sewell smatraju da teorija modernoga svjetskog sistema ima primjere koji uspješno koriste analizu kontingentnih događaja i ovisnosti o prijeđenom putu (Mahoney, 2000: 521; Sewell, 2005: 87).
} 
izrazito osjetljivih na događaje koji se odvijaju u ranim etapama potpune historijske sekvence«; drugo, to da su »u sekvenci ovisnosti o prijeđenom putu, rani povijesni događaji kontingentna događanja koja ne mogu biti objašnjena na osnovi prijašnjih događaja ili 'inicijalnih uvjeta' «, te treće da su sekvence ovisnosti o prijeđenom putu »označene relativno determinističkim kauzalnim obrascima ili onim što bi se moglo smatrati 'inercijom' " (Mahoney, 2000: 510-511). Treći je uvjet osobito koristan za objašnjavanje razvoja ekonomije u jednom povijesnom razdoblju i teškoća u promjeni poluperifernog ili perifernog položaja. Mahoney spominje kako postoje uvjeti, iako ih ne razrađuje, koji uzrokuju preokretanje ovisnosti o prijeđenom putu, što je pak korisno za razumijevanje promjene položaja u modernom svjetskom sustavu. U slučaju hrvatskog položaja u svjetskom sustavu čini se da su kontingentni događaji i stvarali i preokretali sekvencu ovisnosti o prijeđenom putu.

Utjecaj geopolitičkih potresa na hrvatsku ekonomiju, kao i stvaranje i preokretanje ovisnosti o prijeđenom putu, analizirani su kroz povijest nastanka, razvoja, pa i raspada hrvatskih visokotehnoloških poduzeća u 20. i početkom 21. stoljeća. U hrvatskom slučaju analizirani su događaji dovodili do promjena u obujmu i karakteristikama unutarnjeg tržišta, a u vremenu nakon stjecanja hrvatske nezavisnosti utjecali su na zakašnjeli pristup tržištima Srednjoeuropskog ugovora o slobodnoj trgovini (CEFTA) i Europske unije (EU) u usporedbi s drugim srednjoeuropskim konkurentima. Također, ti su događaji utjecali na pristup tržištima zemalja jezgre i, što je posebno bitno, investicijama iz tih zemalja. Posebno za ekonomije s malim unutarnjim tržištima pristup vanjskim tržištima od je presudne važnosti. Tu je činjenicu Wallerstein analizirao već na primjeru Češke i Rusije u 16. stoljeću. Za njih je važnost izvoza različita i ne može se direktno uspoređivati, jer je Češka bila ovisnija o pristupu europskoj svjetskoj privredi (Wallerstein, 1986 [1974, 1980]: 232).

Za analizu položaja hrvatske ekonomije važno je i sljedeće Wallersteinovo tumačenje: »Poluperiferne države su one koje obično slabe i jačaju. Inteligentna državna politika je u velikoj mjeri povezana s događajima. No [...] državna politika nije glavni pokretač već intervenirajući proces. Mnogi mogu pokušati da značajno preobraze rang svoje države u svjetskoj podjeli rada, ali samo mali broj u tome uspijeva zato što uspjeh jedne države eliminira prilike i alternative ostalih« (Wallerstein, 1986 [1974, 1980]: 400). 


\section{Metodologija istraživanja}

Istraživanje promjena položaja hrvatske ekonomije analizirano je kroz povijest 19 poduzeća koja su 1989. imale registriranu znanstveno-istraživačku djelatnost (Čengić i dr., 1991). Riječ je o organizacijama koje se u analizi hrvatskoga inovacijskog sustava određuje kao jedan od ključnih dijelova tog sustava, a to su korporacijski, tj. industrijski instituti koji opskrbljuju svoja poduzeća inovacijama i razvojem proizvoda (Švarc, 2009: 121). ${ }^{5}$ Poduzeća s industrijskim institutima tretiraju se kao visokotehnološka poduzeća jer su se u njima istovremeno odvijala znanstvena istraživanja i proizvodnja. Ona omogućuju prelazak na ekonomiju temeljenu na znanju i približavanje zemljama jezgre koje upravo u tom tipu ekonomije dominiraju u svjetskoj podjeli rada.

Njihov popis (vidi Tablica 2) upućuje na to da je riječ i o većem broju najznačajnijih poduzeća hrvatske ekonomije. Dakako, ona ne mogu reprezentirati cjelokupno hrvatsko gospodarstvo, ali ova su dala znatan doprinos rastu hrvatskog BDP-a i to ne samo kroz svoje osnovne djelatnosti proizvodnje i izvoza. Posebno u ovdje dominantno analiziranom razdoblju, onom socijalističke Jugoslavije, analizirana poduzeća su intenzivno poticala i izgradnju stanova za svoje zaposlenike. Gradnja stanova je najvažnija kategorija neprivrednih investicija i kako se zasnivala na vlastitim kapacitetima građenja, imala je »izuzetan multiplicirajući utjecaj na nacionalnu proizvodnju« (Sirotković, 2000: 20). Osim kvantitativnog doprinosa ekonomskom rastu, ta su poduzeća imala i snažnu simboličku ulogu u jugoslavenskom i hrvatskom društvu. Njihova veličina i položaji u globalnoj trgovini pridonosili su stvaranju percepcije da domaća ekonomija posjeduje poduzeća koja se mogu ravnopravno nositi sa svjetskim poduzećima i izvoziti svoje proizvode i znanje, ponajviše u zemlje Srednje i Istočne Europe i Trećeg svijeta, ali i u zemlje Zapada.

Popis poduzeća koja su 1989. imale registriranu znanstveno-istraživač$\mathrm{ku}$ djelatnost uspoređen je s istim takvim popisom iz 2017. kako bi se vidjelo koliko je od njih zadržalo taj status. Analizirana su i nova poduzeća koja imaju registriranu znanstvenu djelatnost, ${ }^{6}$ no ona u ovom članku

\footnotetext{
${ }^{5}$ Zbog tog su razloga iz istraživanja isključena tri poduzeća. GEOTEHNIKA i Institut za elektroprivredu, jer se radilo o poduzećima koja su ponajprije pružala inženjerske i projektne usluge, a koje se danas označava kao samostalne tržišne institute (Švarc, 2009). Također, izbačen je i PTT kao poduzeće koje je bilo usmjereno na pružanje javnih usluga. ${ }^{6} \mathrm{http} / / /$ pregledi.mzos.hr/Ustanove_Z.aspx.
} 
nisu u fokusu. Provedeno je 20 eksploratornih polustrukturiranih intervjua s bivšim ili sadašnjim zaposlenicima poduzeća koja su imala ili danas imaju registriranu znanstveno-istraživačku djelatnost. Kazivači su izabrani ne samo kao akteri tranzicije svojih organizacija (uglavnom su to bili ljudi s rukovodećim iskustvom i znanstvenim zvanjima), nego i kao vrsni poznavatelji industrijskih sektora kojima pripadaju njihove organizacije, ali i cjelokupnoga hrvatskog istraživačko-razvojnog sektora. Treba naglasiti da kazivači nisu samo govorili o povijesti, sadašnjosti i budućnosti svojih organizacija, nego su im postavljana i općenita pitanja o razvoju i stanju hrvatskoga istraživačko-razvojnog sektora, a u što su često bila uključena i njihova razmatranja o ostalim analiziranim tvrtkama s posebnim naglaskom na konkurentska poduzeća koja djeluju u njihovom sektoru. Intervjui su vođeni od travnja do prosinca 2014. Prosječno trajanje intervju iznosilo je 82 minute, a rezultati intervjua upućivali su na potrebu detaljnije analize položaja hrvatskih visokotehnoloških poduzeća u modernom svjetskom sustavu.

Kvalitativno istraživanje nastanka i razvoja hrvatskih visokotehnoloških poduzeća provedeno je kroz analizu službenih monografija poduzeća i internetskih stranica, arhivske građe, ali i korištenjem drugih izvora o tim poduzećima: znanstvenih i novinskih članaka te knjiga koje su se bavile tim poduzećima. Kako korijeni nekih od njih sežu i do stotinjak godina u prošlost, nije bilo uvijek moguće u potpunosti rekonstruirati njihovu povijest, tako da se ovdje prikazuju samo glavne tendencije razvoja. Posebno se to odnosi na ona poduzeća koja su ugašena ili su izgubila vezu sa svojom tradicijom te nije bilo moguće naći dovoljno iscrpne izvore koji bi omogućili prikupljanje svih potrebnih podataka. Istraživanje povijesti hrvatskih poduzeća omogućuje i usporedbu s povijestima poduzeća iz srednjoeuropskih zemalja s kojima se Hrvatska najčešće uspoređuje, ali uglavnom na agregatnom nivou.

\section{Nakon Prvoga svjetskog rata: strani kapital i osnivanje hrvatskih visokotehnoloških poduzeća u monarhističkoj Jugoslaviji}

Prvi svjetski rat bio je disruptivan događaj koji je znatno usmjerio procese industrijalizacije u Hrvatskoj. Kontingentnost nastanka i razvoja hrvatske industrije i njezino pozicioniranje unutar odnosa jezgre, poluperiferije i periferije može se razumjeti upravo iz razdoblja između dvaju svjetskih ratova. Nakon što su hrvatski krajevi unutar Austro-Ugarske bili periferija i u političkom i u ekonomskom smislu oni su unutar Kraljevine Srba, Hrvata i Slovenaca, zajedno sa slovenskim krajevima, postali centar industrijalizaci- 
je (o transformaciji Zagreba u »gospodarsko središte nove države« v. Žebec Šilj, 2017: 77). I slovenska i hrvatska industrija profitirale su od novoga zajedničkog tržišta zaštićenog vanjskom carinom i ulaskom stranog kapitala koji je preferirao sjeverozapadne krajeve. Dakako, taj se centralni položaj odnosio samo na sferu stranih ulaganja i razvoja modernih poduzeća, jer se u unitarističkoj Kraljevini provodila politička i ekonomska marginalizacija prostora koji nisu pripadali nekadašnjoj Kraljevini Srbiji (Steindorff, 2006).

Iako su analizirana poduzeća i u 21. stoljeću uglavnom ostala poznata pod nazivima iz socijalističkog razdoblja, većina njih je osnovana ili je imala svoje prethodnice u poduzećima i radionicama iz međuratnog razdoblja (Tablica 2). Također, velik dio poduzeća je osnovan ili moderniziran s pomoću stranog kapitala iz zemalja jezgre i poluperiferije koji nastoji ući na novo, relativno veliko, tržište. ${ }^{7}$ Tako 1921. nastaje Kemičko-farmaceutska industrija Kaštel d.d., buduća PLIVA, kao zajednički projekt zagrebačkoga dioničarskog društva za promet droga i kemikalija Isis i budimpeštanske tvornice lijekova i kemijskih proizvoda Chinoin. Iste godine uz pomoć mađarskog kapitala i seljenjem tvornice iz okolice Budimpešte nastaje Prva jugoslavenska tvornica vagona, strojeva i mostova d.d. Brod na Savi, kasnije Đuro Đaković (Brajdić, 2012), a također i Jugoslavensko Siemens, čije se osnivanje smatra začetkom Končara (Anić, 2011). Kombinat Borovo razvio se pak iz čehoslovačke tvornice Bata, koja je u Borovu otvorena 1931. jer je Tomaš Bata želio izbjeći visoke jugoslavenske carine (Duić-Dunja, 2005).

Ti primjeri pokazuju koliko je ranija industrijalizacija važna za ekspanziju i uspjeh poduzeća. Siemens je osnovan 1847., Bata 1894., a Chinoin 1910., a prošli su više ciklusa modernizacije prije nego što su se počeli širiti na područje jugoistočne Europe koje je bilo bez značajnije tradicije industrijske proizvodnje $u$ tim sektorima. ${ }^{8}$

\footnotetext{
${ }^{7}$ Mora se naglasiti i da su neke tvrtke imale i prijeratne veze s hrvatskim krajevima. Njemački Siemens je sudjelovao u elektrifikaciji Čakovca i Zagreba krajem 19. i početkom 20. stoljeća (Anić, 2011). I hrvatska industrija nafte ima preteču u stranom kapitalu i stranom poduzetništvu iz vremena Austro-Ugarske. Bečki poduzetnik Wilhelm Singer smatra se začetnikom industrijske proizvodnje nafte u hrvatskim krajevima. Singeru je Kraljevina SHS privremeno oduzela imovinu, a nakon što je 1922. postao jugoslavenskim državljaninom vraća mu se imovina. Zatim je 1923. utemeljio naftno poduzeće Međimursko petrolejsko d.d. koje je privlačilo strani kapital i jedna je od preteča INA-e (Belošić, 2002).

${ }^{8}$ Bata i Chinoin su i primjer rane ekonomske globalizacije potaknute iz Srednje Europe. Bata je imala snažnu ekspanziju tridesetih godina 20. stoljeća i svoje tvornice diljem svijeta, od Brazila preko Francuske do Jave. Chinoin je pak imao distribuciju svojih proizvoda u Meksiku.
} 
Tablica 2. Nastanak hrvatskih visokotehnoloških poduzeća i njihove temeljne karakteristike u međuratnom razdoblju

\begin{tabular}{|c|c|c|c|}
\hline $\begin{array}{l}\text { naziv poduzeća } u \\
\text { socijalizmu }\end{array}$ & $\begin{array}{l}\text { godina } \\
\text { utemeljenja } \\
\text { poduzeća }{ }^{10}\end{array}$ & $\begin{array}{l}\text { status ili naziv poduzeća } \\
\text { u međuratnom razdoblju } \\
\text { (poduzeća iza kojih } \\
\text { slijedi zagrada sodinom } \\
\text { osnivanja nedominantne su } \\
\text { i neizravne prethodnice) }\end{array}$ & $\begin{array}{l}\text { prisutnost stranog } \\
\text { kapitala u međuratnom } \\
\text { razdoblju u poduzeću } \\
\text { ili u nekom od } \\
\text { poduzeća prethodnica }\end{array}$ \\
\hline 1. CHROMOS & 1920. & $\begin{array}{l}\text { Moster, Chromos (1923.), } \\
\text { Kutrilin (1930.) }\end{array}$ & + (njemački, austrijski) \\
\hline 2. PLIVA & 1921. & $\begin{array}{l}\text { Kemičko-farmaceutska } \\
\text { industrija Kaštel }\end{array}$ & $+($ mađarski) \\
\hline 3. ĐURO ĐAKOVIĆ & 1921. & $\begin{array}{l}\text { Prva jugoslavenska tvornica } \\
\text { vagona, strojeva i mostova } \\
\text { d.d. Brod na Savi }\end{array}$ & + (mađarska) \\
\hline 4. RADE KONČAR & 1921. & Jugoslavensko Siemens & + (njemački) \\
\hline 5. BRODOSPLIT & 1922. & $\begin{array}{l}\text { Pomorsko industrijsko i } \\
\text { tehničko poduzeće Braća } \\
\text { Matijević }\end{array}$ & $+($ francuski) \\
\hline 6. BOROVO & 1931. & Bata & + (češki) \\
\hline 7. ŽELJEZARA SISAK & 1938. & $\begin{array}{l}\text { Rudarsko udruženje - } \\
\text { Talionica Caprag }\end{array}$ & + (njemački) \\
\hline 8. PRVOMAJSKA & 1946. & $\begin{array}{l}\text { Radionica Braća Ševčik } \\
\text { (1922.) }\end{array}$ & - \\
\hline 9. PODRAVKA & 1947. & $\begin{array}{l}\text { Radionica brace Wolf } \\
(1934 .)\end{array}$ & - \\
\hline 10. FOTOKEMIKA & 1947. & Ozacel (1936.) & + (njemački) \\
\hline 11. RIZ & 1948. & $-{ }^{11}$ & - \\
\hline 12. NIKOLA TESLA & 1949. & $\begin{array}{l}\text { Fuld, društvo za automatsku } \\
\text { telefoniju (1933.) }\end{array}$ & + (njemački, švicarski) \\
\hline
\end{tabular}

\footnotetext{
${ }^{9}$ Nazivi poduzeća preuzeti su iz Čengić i dr., 1991., i odnose se na vrijeme s kraja socijalističkog razdoblja.

${ }^{10}$ Nastanak poduzeća često je teško točno odrediti, jer postoje različite interpretacije kad je poduzeće nastalo i kad se može govoriti o kontinuiranom postojanju poduzeća. Te su se interpretacije mijenjale s političkim promjenama pa se tako u počecima socijalističke Jugoslavije često željelo zatomiti predratnu tradiciju novih poduzeća. Ovdje je primijenjen kriterij izravne veze s poduzećem iz prethodnog razdoblja (nacionalizacija poduzeća ili spajanje poduzeća u kojoj jedno od poduzeća ima dominantu ulogu). Kao godina nastanka poduzeća isključeno je osnivanje radionica, poljoprivrednih dobara ili poduzeća prethodnica koja nisu bila dominantna u spojenim poduzećima nakon Drugoga svjetskog rata.

${ }^{11} \mathrm{U}$ međuratnom je razdoblju postojala zagrebačka tvornica radijskih prijamnika Pan s istim nazivom kao i bečki proizvođač prijamnika. RIZ je svoju početnu proizvodnju obavljao u prostorijama Pan-radija, a istraživanjem veza između RIZ-a i Pan-radija bave se istraživači povijesti radija u Hrvatskoj (http://www.radiomuseum-croatia.com/new/panradiozagreb).
} 


\begin{tabular}{|c|c|c|c|}
\hline $\begin{array}{l}\text { naziv poduzeća } u \\
\text { socijalizmu }\end{array}$ & $\begin{array}{l}\text { godina } \\
\text { utemeljenja } \\
\text { poduzeća }\end{array}$ & $\begin{array}{l}\text { status ili naziv poduzeća } \\
\text { u međuratnom razdoblju } \\
\text { (poduzeća iza kojih } \\
\text { slijedi zagrada s godinom } \\
\text { osnivanja nedominantne su } \\
\text { i neizravne prethodnice) }\end{array}$ & $\begin{array}{l}\text { prisutnost stranog } \\
\text { kapitala u međuratnom } \\
\text { razdoblju u poduzeću } \\
\text { ili u nekom od } \\
\text { poduzéca prethodnica }\end{array}$ \\
\hline 13. JUGOTURBINA & 1949. & - & - \\
\hline 14. INA & 1952. & $\begin{array}{l}\text { Anglo-jugoslavensko } \\
\text { petrolejsko d.d. (1921.); } \\
\text { ROMSA a.d. (1922.); } \\
\text { Međimursko petrolejsko } \\
\text { d.d. (1923.) }\end{array}$ & $\begin{array}{l}+ \text { (britanski, njemački, } \\
\text { talijanski, mađarski, } \\
\text { nizozemski, švicarski) }\end{array}$ \\
\hline 15. PIK BELJE & 1953. & Državno dobro & - \\
\hline 16. IPK OSIJEK & 1960. & $\begin{array}{l}\text { Prvo hrvatsko-slavonsko } \\
\text { dioničko društvo za } \\
\text { industriju šećera (1905.); } \\
\text { Prva osječka tvornica } \\
\text { kandita Kaiser i Stark } \\
\text { (1920.); Tvornica keksa } \\
\text { Karolina (1921.) }\end{array}$ & - \\
\hline 17. KOKA & 1961. & - & - \\
\hline 18. ATM & 1963. & - & - \\
\hline 19. PK ZADAR & 1976. & - & - \\
\hline
\end{tabular}

Dakako, strani kapital nije dolazio na europsku periferiju kako bi modernizirao zaostale krajeve, jer je, kao i u Wallersteinovoj teoriji, njegov cilj bio iskorištavanje sirovinskog bogatstva i jeftine radne snage (KolarDimitrijević, 1990: 188; Karaman 1991), ali i pristup novom rastućem jugoslavenskom tržištu. No, nenamjeravana posljedica prisutnosti stranog kapitala mogu biti modernizacijski procesi koji su omogućavali kako lakše uključivanje poduzeća i pojedinaca u svjetske tokove proizvoda i znanja, tako i preoblikovanje lokalnih sredina. Primjerice, izgradnja Batinog naselja je znatno pridonijela industrijalizaciji i urbanizaciji vukovarskog kraja i omogućilo daljnje širenje kombinata Borovo u socijalističkoj Jugoslaviji. ${ }^{12}$ Značajna je početkom 20. stoljeća bila i uloga drugih čeških poduzetnika

\footnotetext{
${ }^{12}$ Možda je najbolji primjer složenog odnosa eksploatacije i modernizacije priča s kraja 19. stoljeća o nastanku grada Belišća koje se razvilo iz industrijskog pogona mađarskog Židova Edmunda Gutmanna. Gutmann je u valpovački kraj došao na poziv valpovačkih vlastelina koji »nisu bili u stanju organizirati industrijsku preradu vlastite sirovinske baze zbog financijske oskudice, pa su zato tražili pomoć izvana« (Volner, 2012: 181). Tako je iz eksploatacije šumskih resursa, a koja se opravdano smatra simbolom eksploatacije perifernih krajeva i ljudi (Karaman, 1991), nastala moderna drvna industrija te prometna i urbana infrastruktura iz koje je nastao grad Belišće, a poslije i socijalistički Kombinat Belišće.
} 
koji su poticali razvoj hrvatske industrije. Češki obrtnici braća Ševčik osnovali su tako 1922. radionicu, prethodnicu tvornice Prvomajska. ${ }^{13}$

Primjeri poduzetnika Gutmanna i Singera, ali i razvoja gradova Pule i Rijeke pokazuju razliku između prekomorske kolonizacije afričkih i azijskih prostora i unutarnje kolonizacije koju su provodili Beč i Budimpešta. Zbog geografske blizine, a nekad i direktne uprave nad tim krajevima iz austro-ugarskih centara, odnos između kolonizatora i koloniziranih krajeva bio je manje jednosmjeran u slučaju te unutarnje kolonizacija od prekomorske kolonizacije koju su provodile zapadnoeuropske države. U 19. stoljeću i početkom 20. stoljeća europska je poluperiferija eksploatirajući resurse iz europske periferije znatnije utjecala na razvoj industrijalizacije i prometa. Kad su se geopolitički uvjeti promijenili, te su materijalne tragove, pa i poduzetnike, koristile i novonastale države. No, postojala je i razlika u odnosu europske poluperiferije prema različitim krajevima koji danas čine Republiku Hrvatsku. Razlika je proizlazila iz geopolitičkih i geografskih razloga, pa je tako Beč ulagao u Pulu i njezinu brodogradnju da bi konkurirao ujedinjenoj Italiji, a Budimpešta je Rijeku vidjela kao svoj najbliži izlaz na more. Ti su gradovi tako postojali dio europske poluperiferije. S druge strane, udaljeniji i teže dostupniji krajevi ostajali su europska periferija, pa je Dalmaciju jedan bečki vlasnik dalmatinskih ugljenokopa smatrao dostojnom zamjenom za prekomorske kolonije, a koja bi Habsburškoj monarhiji omogućila povratak na stare staze slave (Karaman, 1991: 186). Dakle, neki su krajevi bili u većoj mjeri eksploatirani od drugih, bez dodatne modernizacije, a taj se nejednaki stupanj eksploatacije nastavio i u monarhističkoj Jugoslaviji. I dok su se posebno zagrebačko područje, ali i neke urbaniziranije slavonske i dalmatinske sredine, industrijalizirale s pomoću stranog kapitala, Belje se, kao jedno od najvećih europskih poljoprivrednih imanja, u međuratnom razdoblju našlo $u$ teškom položaju. Pod vlašću Habsburgovaca u 19. i početkom 20. stoljeća, ono je prolazilo kroz modernizaciju i razvoj prerađivačkih kapaciteta. Nakon Prvoga svjetskog rata u njemu je vladala nesigurnost i izostanak modernizacije i ekonomije obujma, jer je dio pripao Mađarskoj, a dio Jugoslaviji. Karađorđevići su postali vlasnici Belja i nisu dopuštali ulazak stranog kapitala (Kolar-Dimitrijević, 1998).

\footnotetext{
${ }_{13}$ Ivan Paspa je pak dvadesetih godina 20. stoljeća osnovao tvornicu baterija Croatia, a češki Židov Julije König još je 1911. osnovao prvu tvornicu čokolade u jugoistočnoj Europi Union, koja će 1950., ujedinjenjem s drugim zagrebačkim konditorskim poduzećima, prerasti u Kraš. Treba naglasiti i to da su i u drugoj polovini 19. stoljeća dinastije u zagrebačkim poslovnim elitama bile dobrim dijelom nehrvatskoga, pretežno židovskog podrijetla (Iveljić, 2007)
} 
Osim što je sudjelovao u osnivanju poduzeća, strani kapital je utjecao i na modernizaciju domaćih poduzeća. Brodogradilište Split, danas Brodosplit, imalo je visok udio francuskog kapitala tako da su sredinom tridesetih godina njime upravljali francuski menadžeri što je utjecalo na njegov brzi uspon (Belamarić, 2008). Tvornica Moster, iz koje se razvio kombinat Chromos, spletom je okolnosti došla »u zavisnost od najvećeg njemačkog kemijskog koncerna I.G. Farbenindustrie« (Chromos, 1970: 5). Moster je dominirao u proizvodnji premaznih sredstava na prostoru cijele Jugoslavije, a rekonstrukcija tvornice završena je 1939.

I nastanak onih poduzeća koja su osnivali isključivo domaći poduzetnici ovisio je o europskim geopolitičkim kretanjima. Tako je nastanak Talionice Caprag, iz koje će se razviti Željezara Sisak, potaknulo to da je krajem »tridesetih godina, u vrijeme intenzivnih priprema sila osovina za rat, u Evropi [...] naglo porasla potražnja čelika« (Čepo, 1974: 19). Nacistička je Njemačka od sredine tridesetih godina intenzivno radila na uključivanju država jugoistočne Europe, među njima i Jugoslavije, u njemački privredni prostor, a odnos se temeljio na njemačkom uvozu sirovina i izvozu industrijskih proizvoda (Berend, 2012). No, bilo je i suprotnih razmjena pa je tako »zahvaljujući koksu uvezenom iz Trećeg Reicha, a vjerojatno i njemačkim kreditima, željezara Sisak [...] 1940. proizvela 19.561 tonu sirovoga bijelog željeza, što je bila najveća proizvodnja sve do 1947. godine« (Kolar-Dimitrijević, 1990: 182). Pripreme za Drugi svjetski rat utjecale su na intenzivniji razvoj i nekih drugih analiziranih poduzeća. Tehnološki razvoj riječke rafinerije nafte (ROMSA), koja je od 1926. bila u vlasništvu talijanske naftne kompanije AGIP, bio je vezan uz opskrbljivanje talijanskog pohoda na Etiopiju 1935. (Đekić, 2012). U razdoblju 1935. 1940. hrvatsko se gospodarstvo oporavlja i na kraju tog razdoblja BDP po stanovniku premašuje iznos s početka svjetske ekonomske krize iz 1929. (Stipetić, 2012).

U razdoblju Nezavisne Države Hrvatske, kad je hrvatska ekonomija bila ponajprije dio ekonomije Trećeg Reicha, eksploatacijski je karakter bio posebno prisutan, a hrvatska je ekonomija izgubila mogućnost razvijanja poluperifernog statusa $u$ vidu trajne veze između europske jezgre i slabo industrijaliziranog Balkana. No, i u tom razdoblju ima primjera geopolitičkih utjecaja pa je nacistička industrijalizacija imala utjecaj na razvoj nekih industrija. Radionica braće Ševčik sudjelovala je u održavanju njemačkoga ratnog stroja, a to im je vjerojatno pomoglo da su 1942. odlukom zagre- 
bačkog poglavarstva unaprijeđeni u veleobrt (Gradsko poglavarstvo Zagreb, 1942). Kod Maribora je 1941. Treći Reich izgradio tvornicu za proizvodnju dijelova za avione iz koje će se nakon rata razviti TAM. I ovdje se može uočiti važnost geopolitičkih faktora koji utječu na razliku između direktne industrijalizacije, koju nacistička Njemačka provodi na okupiranim slovenskim područjima koja smatra svojima i koja rezultira izgradnjom novih pogona, i indirektne industrijalizacije na području njima savezničke NDH, gdje se samo intenzivira stara proizvodnja za njemačke vojne potrebe.

\section{Nakon Rezolucije Informbiroa: hrvatska visokotehnološka poduzeća kao most između Zapada i Istoka}

Novonastala socijalistička Jugoslavija koristila je ekonomsko nasljeđe režima čijim je ideologijama bila direktno suprotstavljena. Socijalistička Jugoslavija je, osim zapadnoeuropske industrijalizacije iz vremena monarhističke Jugoslavije, koristila i ostatke nacističke industrijalizacije, kao u primjerima Željezare Sisak i TAM-a. Ni dva velika prevrata, kao što su nestanak monarhističke Jugoslavije i raznih režima koji su uspostavljeni u vrijeme Drugoga svjetskog rata, nisu posve uklonili dijelove prijeratne povezanosti sa zapadnoeuropskom modernizacijom. Zapadni su industrijalizacijski poticaji iz međuratnog razdoblja ostali prisutni u brojnim socijalističkim poduzećima. Tako se kroničar Brodosplita Igor Belamarić prisjeća da je kao mladi inženjer koji je 1952. došao u brodogradilište često »slušao o predratnim danima francuske uprave« (Belamarić, 2009: 11). Neposredno nakon Drugoga svjetskog rata neka od analiziranih poduzeća osnovana su procesom nacionalizacije privatnih radionica i obrta, kao u primjeru Prvomajske koja je nastala iz veleobrta Braća Ševčik 1946. ili Podravke koja je nastala nacionalizacijom radionice braće Wolf 1947. U slučaju Končara »radnici montažne radionice - bivše vlasništvo Siemens d.d. daju svom pogonu ime Rade Končar u znak sjećanja na poginulog druga« (Rade Končar, 1981: 6), a zatim je 1946. dekretom jugoslavenske vlade, koji je potpisao Josip Broz Tito, osnovano samostalno poduzeće Rade Končar. ${ }^{14}$ Taj je skok

${ }^{14}$ Zanimljivo je pratiti odnos službenih Končarovih monografija prema predratnoj povijesti. U ranijoj monografiji koja nosi podnaslov »Petnaest godina poduzeća i deset godina radničkog upravljanja« Siemens se najviše spominje kao radionica u kojoj je Rade Končar bio sindikalist (Škrgatić i Mandić 1960). U novije se vrijeme pak Končar ponosi svojom stoljetnom poviješću (http://www.koncar.hr/o-nama/tradicija/). O tome kako i zašto poduzeća ideološki konstruiraju i rekonstruiraju svoju povijest i sadašnjost vidi i na slučaju Agrokora (Petrović, 2008). 
prema snažnijoj industrijalizaciji bio rezultat poslijeratne obnove i političkih poticaja, no u analiziranim se slučajevima često nastavljao na predratnu industrijalizaciju potaknutu iz srednjoeuropskih i zapadnoeuropskih ekonomija (Žebec Šilj, 2017).

Poslijeratna se industrijalizacija razvila kroz dva snažna geopolitička poticaja. Industrijski razvoj temeljio se na petogodišnjem planu razvoja 1947. - 1951. koji je bio usmjeren na elektrifikaciju i industrijalizaciju, ponajprije tešku industriju, i kopirao je sovjetski model. No, taj petogodišnji plan je uskoro dobio i drugi neočekivani geopolitički poticaj, koji će je približiti zemljama jezgre. Rezolucija Informbiroa, koja je suprotno jugoslavenskoj mitologiji značila »Staljinovo 'ne' Titu« (Jakovina, 2010), bio je događaj koji je pokrenuo lanac događaja koji su mijenjali strukturu dugog trajanja, tj. prednost Srednje Europe u pristupu zemljama kapitalističke jezgre pred Jugoslavijom. Neposredno nakon Rezolucije Informbiroa socijalistička se Jugoslavija našla u teškoj međunarodnoj poziciji, ali i unutarnjoj. Zbog posljedica izolacije prijetilo je izbijanje masovne gladi, što je dodatno potaknulo Tita na približavanje Zapadu (Jakovina, 2002). SAD je nakon toga počeo slati ekonomsku pomoć, čime je i zaustavljena glad u Jugoslaviji, a uskoro i vojnu pomoć. Kao što se vidi iz tijeka događaja Tito se našao pred odlukama koje su zahtijevale ili njegovo povlačenje ili pokušaj preživljavanja u sve više podijeljenom hladnoratovskom svijetu, a što ga je usmjerilo prema Zapadu. ${ }^{15}$

Prednost Jugoslavije pred državama Srednje Europe, koje su geografski i po stupnju industrijalizacije bliže europskoj jezgri, bila je u tome što su one postale eksploatirana periferija SSSR-a. SAD je svojim saveznicima, osobito u poslijeratnim godinama, pružao pomoć. Tu činjenicu priznaju i revizionistički povjesničari Hladnog rata kao Douglas Rivero, koji piše kako je količina resursa koje je SSSR povukao iz zemalja Istočne Europe kako bi se obnovio, bila jednaka onoj koju je SAD poslao u Zapadnu Europu kroz Marshallov plan. Eksploatacija se nastavljala i kroz sovjetski uvoz iz europskih socijalističkih zemlja po nižim cijenama i izvoz u iste te zemlje po višim cijenama (Rivero, 2012).

\footnotetext{
${ }^{15}$ Drugi »otpadnički« europski socijalistički režimi imali su kasnije i druge opcije za savezništvo osim ono sa Zapadom. Tako su se socijalistička Albanija, u većoj mjeri, i socijalistička Rumunjska, u manjoj mjeri, približili Kini. Zanimljivo je za razumijevanje položaja socijalističke periferije da je njihov sukob sa Sovjetskim Savezom prouzročen i pokušajem da se unutar Savjeta za ekonomsku pomoć zemlje ekonomski specijaliziraju, a Albanija i Rumunjska trebale su imati ulogu razvijanja poljoprivrede za industrijalizirane članice.
} 
Iako je bila američki komunistički saveznik, Jugoslavija je ipak bila samo komunistički saveznik koji je imao turbulentne odnose s SAD-om (Jakovina, 2002, 2003). Zbog tog se razloga Jugoslavija, za razliku od zemalja Zapadnog bloka, nije mogla posve pouzdati u američku zaštitu i morala se oslanjati na svoje snage. Zbog specifičnog položaja izvan blokova, Jugoslavija je značajno ulagala u razvoj vojske i vojne industrije. Nakon 1949. vojni budžet se u sljedećih nekoliko godina penje do $23 \%$ nacionalnog dohotka, a što je bio jedan od najvećih udjela u svijetu (Bilandžić, 1985). Jugoslavenska narodna armija (JNA) je 10\% svog proračuna trošila na znanstvena istraživanja (Vučinić, Nikezić i Todorović, 1989). Vojska je tako postala iznimno značajan ekonomski i društveni akter koji će utjecati i na razvoj istraživačko-razvojnog sektora kroz cijelo razdoblje socijalističke Jugoslavije.

Kao što je već pokazano na primjeru tvornice Tesla, u razdoblju nakon razlaza sa Sovjetskim Savezom počinje se intenzivno poticati razvoj nezavisne industrije, posebno one bitne za vojnu samostalnost Jugoslavije. Jugoturbina je osnovana 1949. u Karlovcu i to sljedećom vojnom naredbom s potpisom generala Ivana Gošnjaka: »Naređujem da se u Karlovcu izgradi tvornica parnih turbina za potrebe ratne i trgovačke mornarice« (Butković, 2005: 7). Ne samo da su u Hrvatskoj postojali specijalizirani vojni instituti poput Brodarskog instituta, nego su i industrijski instituti Brodosplita, RIZa, Tesle, Đure Đakovića i Končara radili na važnim projektima za potrebe vojske. Kao što jedan kazivač kaže o tom obliku suradnje koji se odvijao i osamdesetih godina: »Vojska je angažirala cijeli tim. Ali je bilo, tada je to bilo, da su bili uključeni i fakulteti i industrija« (Kazivač 4). Dakle, za vojne potrebe je povezivana akademija, vojska i industrija i razvijao se svojevrsni vojno-industrijski kompleks. Osim što je poticala inovacije, vojska socijalističke Jugoslavije bila je i masovni potrošač roba koje su ta poduzeća proizvodile. Primjerice, u Borovu, koji je proizvodio obuću za brojnu vojsku, ili u Podravki, koja je vojsku hranila. Zanimljiv je primjer utjecaja proizvodnje za vojsku na daljnje inoviranje proizvoda. U Podravki je sušenje povrća počelo 1952. upravo za potrebe JNA, da bi se 1957. sušeno povrće počelo koristiti za početnu proizvodnju jušnih koncentrata koji su postali jedan od najznačajnijih Podravkinih proizvoda (Bartl i Vucelić, 1983). Iste godine je Fotokemika ostvarila napredak u proizvodnji fotografskih razvijača, jer je tada došlo do prve veće narudžbe, i to za JNA (Doljak, 1955). 
Dakako, nagli prekid s SSSR-om isprva je donosio štete poduzećima, jer je zaustavio već započetu industrijalizaciju koja je dolazila iz Istočnog bloka. U Željezari Sisak je 1948., nakon što Mađarska nije isporučila željeznu konstrukciju, obustavljena izgradnja valjaonice bešavnih cijevi. No, radovi su nastavljeni 1950., a oprema je tada već nabavljana u Italiji. U gradnji jednoga drugog postrojenja u Željezari Sisak iste su godine sudjelovali ne samo njemački i švicarski proizvođači i stručnjaci, nego i stručnjaci iz Đure Đakovića i Končara (Čepo, 1974). Već se dakle od 1950. može govoriti o počecima kombiniranja zapadne industrijalizacije i one unutarnje koju zajednički provode domaća poduzeća.

Kako geopolitički kontekst i slučajan događaj mogu odrediti sudbinu jedne tvrtke i stvoriti ovisnost o prijeđenom putu, pokazuje susret Tvornice Tesla sa zapadnom modernizacijom. Sredinom 1951. jugoslavenska pošta uputila je poziv jugoslavenskim tvornicama da pošalju svoje stručnjake u inozemstvo kako bi se modernizirao telefonski sustav. Jedina zainteresirana tvornica je bila Tesla, a njihov je stručnjak posjetio i švedski Ericsson. Ericssonova su rješenja na kraju odabrana kao najbolja te je po njihovoj licenciji Tesla počela proizvoditi telefonske centrale. Zanimljivo je da je uskoro slovenska Iskra požalila što nije prihvatila poziv na slanje svojih stručnjaka u inozemstvu te je 1955. i ona željela proizvoditi po Ericssonovoj licenciji, ali joj je jugoslavenska pošta to onemogućila (Bahtijari, 2009).

U godinama neposredno nakon prekida sa Staljinom događa se i intenzivna modernizacija budućih vedeta hrvatskog i jugoslavenskoga visokotehnološkog izvoza, jer su se i Končar i PLIVA te godine snažnije usmjerili na vlastiti razvoj. Odmah nakon što je obustavljena isporuka generatora iz zemalja Istočnog bloka, Končar 1949. započinje razvoj i proizvodnju automatskih regulatora napona za sinkrone generatore. Upravo će u području magnetskih regulatora napona i sistema uzbude sinkronih generatora Končar sljedećih desetljeća postizati značajne izvozne rezultate (Car, 2011). I u slučaju razvoja generatora može se uočiti važnost Sewellova naglaska na potrebi izučavanja složenih odnosa kontinuiteta i iznenadnih prekida. Prijeratna i ratna tradicija Siemensove proizvodnje i prenošenja tih znanja na Zagrebačkom sveučilištu preživjela je u Končaru kroz ključne profesore i mlade inženjere koji su zatim sudjelovali i u poslijeratnom Končarovom razvoju (Ožanić, 2016). No, geopolitički poticaj, tj. izolacija Jugoslavije bili su ključni za početak intenzivnoga samostalnog razvoja Končara. PLIVA se također od 1950. „ «ubrzano razvija što je rezultat rada istraživača, 
usvajanja novih proizvodnih tehnologija i izgradnje novih kapaciteta« (Šćrbačić, 1981: 2).

Uskoro je došlo i do osnivanja industrijskih instituta, što je bio značajan korak prema povezivanju znanosti i proizvodnje i porastu inovativnosti hrvatskog gospodarstva. Tako je PLIVIN institut nastao 1952., a slijedili su ga 1955. Chromosov i 1959. RIZ-ov. Istodobno s postupnim uključivanjem u svjetske ekonomske i inovacijske tokove, nastojalo se dakle i potaknuti vlastiti razvoj. Ipak, veze ovdje analiziranih poduzeća ukazuju na njihov položaj u socijalističkom razdoblju kao svojevrsnih posrednika u distribuciji znanja. Ti nalazi upućuju na poluperiferni status hrvatske ekonomije. Većina je tih poduzeća znanje uvozilo uglavnom iz država jezgre svjetskog sustava, ali i razvijenijih socijalističkih država, ponajviše kao licencije. Znanje su izvozili ponajviše u zemlje poluperiferije i periferije, nešto kroz licencije, ali osobito kroz izvoz znanja i iskustava (know-how prvenstveno za osposobljavanja za proizvodnju tvornica i različitih pogona; Tablica 3). ${ }^{16}$

Tablica 3. Hrvatska visokotehnološka poduzeća u socijalizmu: stvaranje industrijskih instituta te geografske lokacije uvoza i izvoza znanja

\begin{tabular}{|c|c|c|c|}
\hline poduzeće & $\begin{array}{l}\text { godina } \\
\text { stvaranja } \\
\text { instituta }\end{array}$ & zemlje uvoza znanja & zemlje izvoza znanja \\
\hline 1. CHROMOS & 1955. & $\begin{array}{l}\text { Velika Britanija, Danska, } \\
\text { SR Njemačka, Nizozemska, } \\
\text { SSSR }\end{array}$ & Brazil, Italija \\
\hline 2. PLIVA & 1952. & $\begin{array}{l}\text { Švicarska, Velika Britanija, } \\
\text { SR Njemačka, Nizozemska, } \\
\text { SSSR, Japan }\end{array}$ & Indija, Japan, SAD \\
\hline 3. ĐURO ĐAKOVIĆ & 1963. & $\begin{array}{l}\text { SR Njemačka, SAD, } \\
\text { Austrija, Francuska }\end{array}$ & $\begin{array}{l}\text { SSSR, Indija, Sudan, } \\
\text { Etiopija, Turska }\end{array}$ \\
\hline 4. RADE KONČAR & 1961. & $\begin{array}{l}\text { Francuska, SR Njemačka, } \\
\text { Švicarska, Švedska, Italija, } \\
\text { Poljska, SSSR, Nizozemska, } \\
\text { SAD }\end{array}$ & $\begin{array}{l}\text { Poljska, Italija, } \\
\text { Mađarska, Brazil, } \\
\text { Argentina, Indija, Iran, } \\
\text { Venezuela, Velika } \\
\text { Britanija }\end{array}$ \\
\hline 5. BRODOSPLIT & 1983. & Italija, SR Njemačka & $?$ \\
\hline
\end{tabular}

${ }^{16}$ U Tablici 3 dan je pregled država iz kojih se uvozilo i u koje se izvozilo znanje kako bi se otkrio geografski obrazac tokova znanja. Podaci su dobiveni na osnovi službenih povijesti i novinskih izvješća. Kako su takvi tekstovi često usmjereni na samo najznačajnije tokove znanja, a također i s obzirom na već spomenutu nedostupnost cjelovitih prikaza povijesti nekih poduzeća, ovdje se ne može raditi o potpunom pregledu svih tokova znanja. No, o sličnim tokovima znanja na primjerima manjeg broja hrvatskih inovativnih poduzeća pisao je i Radošević (1991). 


\begin{tabular}{|c|c|c|c|}
\hline poduzeće & $\begin{array}{l}\text { godina } \\
\text { stvaranja } \\
\text { instituta }\end{array}$ & zemlje uvoza znanja & zemlje izvoza znanja \\
\hline 6. BOROVO & 1971. & $\begin{array}{l}\text { SR Njemačka, Austrija, } \\
\text { Velika Britanija }\end{array}$ & $?$ \\
\hline 7. ŽELJEZARA SISAK & 1961. & Italija & $?$ \\
\hline 8. PRVOMAJSKA & 1961. & $\begin{array}{l}\text { Velika Britanija, SR } \\
\text { Njemačka, DDR }\end{array}$ & Meksiko \\
\hline 9. PODRAVKA & 1972. & $\begin{array}{l}\text { Njemačka, Japan, SAD, } \\
\text { Danska, Švicarska }\end{array}$ & $\begin{array}{l}\text { Mađarska, Austrija, } \\
\text { Turska }\end{array}$ \\
\hline 10. FOTOKEMIKA & 1952. & Italija, Japan, SAD & Brazil \\
\hline 11. RIZ & 1960. & $\begin{array}{l}\text { Nizozemska, Italija, SAD, } \\
\text { Njemačka }\end{array}$ & $?$ \\
\hline 12. NIKOLA TESLA & 1963. & Švedska, Italija & $\begin{array}{l}\text { SSSR, Mađarska, } \\
\text { Istočna Njemačka, } \\
\text { Kina, Kuba, Albanija, } \\
\text { Poljska }\end{array}$ \\
\hline 13. JUGOTURBINA & 1977. & $\begin{array}{l}\text { Švedska, Švicarska, Velika } \\
\text { Britanija }\end{array}$ & $?$ \\
\hline 14. INA & 1967. & Velika Britanija, SAD & DDR, Mađarska, Iran \\
\hline 15. PIK BELJE & 1975. & $\begin{array}{l}\text { Italija, Francuska, SSSR, } \\
\text { Danska }\end{array}$ & SSSR, Venezuela \\
\hline 16. IPK OSIJEK & 1985. & $\begin{array}{l}\text { SAD, Nizozemska, } \\
\text { Njemačka, Italija, Velika } \\
\text { Britanija }\end{array}$ & $\begin{array}{l}\text { Iran, Sudan, Etiopija, } \\
\text { Venezuela }\end{array}$ \\
\hline 17. KOKA & 1989. & SAD, Nizozemska, Japan & Albanija \\
\hline 18. ATM & $?$ & SR Njemačka & $?$ \\
\hline 19. PK ZADAR & 1987. & Italija & $?$ \\
\hline
\end{tabular}

Specifičan politički položaj Jugoslavije između Istoka i Zapada donosio joj je tržišnu prednost u recepciji i distribuciji inovativnog znanja, ali i proizvoda. Posebno je razrađen protok znanja bio u sklopu Pokreta nesvrstanih, gdje su istraživači iz Hrvatske odlazili u nesvrstane države ili su istraživači iz tih zemalja dolazili na usvajanje znanja u Hrvatsku: »Od nekih većih ugovora o izvozu znanja, nešto malo je bilo u Afriku, i to poslije '61, znači kada je bila ona... nesvrstani u Beogradu, jel. Onda se nešto kao njima pokazivalo. Ali više se išlo na izvoz gotovog proizvoda« (Kazivač 15). Iako ovaj kazivač pokazuje skepsu prema izvozu znanja u zemlje Trećeg svijeta i količinski i prema njezinoj svrsi, on govori o njezinoj političkoj uvjetovanosti, koja je prema njemu rezultat osnivanja Pokreta nesvrstanih 1961. u Beogradu. Drugi kazivač ima drukčiji stav: »E, izvoz znanja je isto bio velik. Mi smo išli sa izvozom znanja u 
Sudan, Etiopiju. Imali smo svoja istraživanja. Mi smo se jedno vrijeme pripremali i za Iran. Učili strane jezike« (Kazivač 14). On u tom inovacijskom toku vidi i širu korist za cijelu državnu ekonomiju: »Ali, to je i za našu firmu značilo indirektno ugovaranje takvih poslova jer je omogućilo državi da na drugim sektorima, je li, isto dođe do izražaja preko ovog sektora« (Kazivač 14).

Iako se ovdje ne analizira detaljno izvoz proizvoda, i njemu je pogodovao specifičan politički položaj Jugoslavije. Na primjer, za izvoz brodova je bilo vrlo važno uspostaviti politički kontakt prije ugovaranja posla. Tome zorno svjedoče fotografije na kojima se vide strani političari najrazličitijih ideoloških usmjerenja koji su posjetili Brodosplit u društvu ili s vodstvom brodogradilišta ili s Titom: etiopski car Haile Selassie 1954., grčki kralj Pavle 1955., predsjednik švedske vlade Tage Erlander 1957., egipatski predsjednik Gamal Abdel Nasser 1958., zapovjednik indonežanske ratne mornarice R. Soebijakto 1959. i sovjetski vođa Nikita Hruščov 1963. (Belamarić, 2009: 566 - 576). Osobito je znakovit bio Hruščovljev posjet, jer je označio jačanje suradnje Jugoslavije sa socijalističkim zemljama (Bilandžić, 1969). Intenziviranje suradnje s Istočnim blokom davalo je hrvatskim firmama posebnu poziciju, a počelo je već nakon prvog Hruščovljeva poboljšanja odnosa s Jugoslavijom 1955. Tesla je tako od 1958. izvozila na rusko tržište, a »riječ je bila o inicijalnom ulazu za zapadnu tehnologiju prema Istočnom bloku, drugim riječima i jedina mogućnost za Ericssonovu tehnologiju u SSSR-u« (Kovačević, 2009: 42).

I druga su poduzeća bila most između Zapada i Istoka, jer su razvijali proizvode i proizvodne procese na osnovi zapadnog znanja, a potom ih izvozili na Istok. Jugoslavija je 1968. imala »trgovinsku razmjenu s više od 120 zemalja, i tako postala jedna od država s najvećim brojem međunarodnih veza na svijetu« (Bilandžić, 1969). No, Hruščovljeve reforme mijenjale su odnose unutar Istočnog bloka, pa su već od šezdesetih godina i manje zemlje članice počele profitirati od regionalnoga ekonomskog bloka (Berend, 2012) i tako smanjivale ekonomsku prednost koja je dolazila od geopolitičke posebnosti Jugoslavije. Ipak, ulazak snaga Varšavskog pakta u Čehoslovačku 1968. pokazao je da se odnosi unutar Istočnog bloka još uvijek temelje na dominaciji SSSR-a. Taj je isti događaj za Jugoslaviju i Europsku ekonomsku zajednicu (EEZ) pokazao važnost jačanja njihovih veza te je bio presudan poticaj za njihovo poli- 
tičko i ekonomsko približavanje, kao i konačno potpisivanje trgovinskog sporazuma 1970. (Tsakaloyannis, 1981).

Neka su poduzeća uspjela izvoziti svoje znanje i na Zapad. Američki Pfizer kupio je 1986. licencu za PLIVIN antibiotik azitromicin i distribuirao ga u SAD-u i Zapadnoj Europi. Ipak, potrebno je staviti te pojedinačne uspjehe u kontekst inovativnosti ostalih država socijalističke Europe, gdje Jugoslavija nije dominirala. Jedina organizacija iz bivše Jugoslavije koja se nalazila među prvih dvadeset organizacija iz bivših europskih socijalističkih zemalja po broju patenata na američkom tržištu u razdoblju od 1969. - 1994. bila je upravo PLIVA, i to tek na 20. mjestu (Radosevic, 1999).

Obrazac nastanka i razvoja hrvatskih poduzeća koji su u socijalizmu uspostavili industrijske institute vrlo je sličan. Nastala su dobrim dijelom na poduzećima koja su bila nacionalizirana nakon Drugoga svjetskog rata, tj. na međuratnim začetcima industrijalizacije potpomognutih stranim kapitalom. Poseban zamah njihovu razvoju, kao i uspostavi novih oblika poduzeća, dala je kombinacija oslanjanja na vlastite snage u sklopu poslijeratne obnove i veza $s$ tehnološki razvijenijim zapadnim poduzećima, što ih je u početku izdizalo u odnosu na konkurenciju s europske poluperiferije i periferije. Suprotno tomu, inovativna poduzeća koja su izrasla iz socijalističkog sustava, a bez znatnijeg utjecaja stranog kapitala i bez poduzeća dominantnih prethodnica, bili su poljoprivredno-industrijski kombinati Belje, Osijek i Zadar. Njihov je razvoj počeo tek nakon napuštanja kolektivizacije poljoprivrede 1953., zbog čega su relativno kasno institucionalizirali znanstveno-istraživačku djelatnost.

\subsection{Nakon naftnih šokova: hrvatska visokotehnološka poduzeća usred globalne krize}

Osamdesete godine označile su krizu jugoslavenskog socijalizma, a na kraju tog desetljeća, analizirajući rezultate istraživanje inovacijskih aktivnosti u velikom broju hrvatskih poduzeća, istraživači su se pitali može li se govoriti o »kraju inovacijske iluzije« (Čengić, Komar i Kraljeta, 1990). Rasprave su se vodile kako u medijima, tako i u samim poduzećima o problemu produktivnosti i uopće potrebi za industrijskim institutima. Radošević navodi problem nepovezanosti industrijskih instituta s proizvodnim djelatnostima i zaključuje kako su mnogi od njih bili više »za pokazivanje« (Radošević, 1994: 499). No, Čengić i suradnici navode frapantnu uspored- 
bu između Philipsova razvojnog instituta, koji je u to vrijeme zapošljavao 10000 istraživača na polju elektronike, i otprilike $2000 \mathrm{u}$ istraživača $\mathrm{u}$ hrvatskim industrijskim institutima (Čengić i dr., 1991), koja je ponajviše svjedočila o iluziji da su inovacije s poluperiferije mogle konkurirati onima iz kapitalističke jezgre. Važnost brojnosti istraživačkog kadra za inovativnost spominje jedan kazivač: »Osnovno je u istraživanju [...] da vi ne možete nikom narediti kreiranje novog proizvoda i da stvori nešto što će se moći prodati. Međutim, kad imate jednu kritičnu masu istraživača, znači jedan broj stručnih ljudi koji se bavi razmišljanjem, nastoje nešto stvoriti, onda iz te kritične mase će proizaći rezultat« (Kazivač 1).

Jednu drugu iluziju, onu kako su društveni problemi kao što je neisplata plaća rezervirani za kapitalističke države, naglasio je kazivač koji je krajem osamdesetih godina radio u odjeljenju »koje nije dobio četiri mjeseca plaće, u socijalizmu« (Kazivač 17). Razotkrivanju takvih iluzija pomoglo je i slabljenje modela geopolitičke rente koji je socijalistička Jugoslavija koristila i nepovoljni novi globalni politički i ekonomski odnosi.

Susan Woodward (1995) pisala je o međunarodnim faktorima koji su utjecali na jugoslavensku krizu osamdesetih godina: globalna recesija iz 1975. i globalna depresija koja je uslijedila. Zapad nakon 1975. postavlja trgovinske barijere, a jugoslavenska se poduzeća sve više orijentiraju na manje zahtjevna istočna tržišta. Najznačajniji događaj koji je utjecao na konstelaciju globalnih odnosa bila je naftna kriza iz 1973. koja je indicirala jačanje političke i ekonomske moći perifernih zemalja. Iako je politički bila bliže zemljama OPEC-a, jugoslavenska ekonomija je po strukturi bila bliže zapadnim zemljama. O tome svjedoči njezina razmjena sa zemljama u razvoju u koje je izvozila industrijske proizvode, a uvozila sirovine, i to osobito naftu iz arapskih zemalja (Mileta, 1986). Jugoslaviju je pak, paradoksalno, politička bliskost sa zemljama OPEC-a skupo koštala krajem osamdesetih godina, jer je sklopila dugoročne ugovore o kupovini nafte po fiksnim cijenama te nije osjetila pad cijena. Zemlje Istočnog bloka pak u to vrijeme počinju od zemalja OPEC-a kupovati naftu po tržišnoj cijeni, a ne više iz SSSR-a (Dekanić, 1990). To je bio novi geopolitički faktor koji je utjecao na poboljšanje položaja srednjoeuropskih socijalističkih zemalja u usporedbi s Jugoslavijom. EEZ je također svoje ekonomske i političke prioritete preusmjerila na zemlje Bliskog istoka, a Jugoslavija je u vrijeme detanta kasnih sedamdesetih godina bivala sve manje strateški zanimljiva (Tsakaloyannis, 1981). 
Povezanost s SAD-om još je uvijek rezultirala znatnim ulaganjima i sedamdesetih godina pa je, primjerice, 1976. potpisan zajednički projekt Dow Chemical-a i INA-e o izgradnji petrokemijskog kompleksa u Omišlju. To je bio najveći zajednički projekt jedne inozemne i jugoslavenske kompanije (Lampe, Prickett i Adamovic, 1990) te je u medijima najavljivan kao najveća američka investicija u jednu socijalističku zemlju. No, početkom 1983. zaustavljen je daljnji razvoj zajedničkog projekta koji su otpočetka pratili različiti problemi, jer se Dow Chemical okreće Saudijskoj Arabiji zbog zasićenosti proizvodnje etilena na europskim tržištima. Očito je da poslovne odluke nisu direktno pratile promjene $\mathrm{u}$ zaoštravanju odnosa SAD-a i SSSR-a koje je krajem sedamdesetih i početkom osamdesetih godina rezultiralo tzv. Drugim hladnim ratom. No, jugoslavenska ekonomija, koja se od početka osamdesetih godina nalazila u režimu odricanja Međunarodnoga monetarnog fonda, nije profitirala od novog zaoštravanja. Ta su zaoštravanja uzrokovala i propadanje poslova koji su koristili poluperifernu poziciju. Početkom osamdesetih godina nastupa embargo na izvoz telekomunikacijskih uređaja u zemlje Istočnog bloka, pa je tako Tesla 1984. zabilježila »najmanji izvoz u odnosu na nekoliko prethodnih godina« (Bahtijari, 2009: 21). Krajem osamdesetih godina na Zapadu se počinje propitivati sigurnost investicija zbog zaoštravanja odnosa u Jugoslaviji. O tome svjedoči situacija u Fotokemiki o kojoj je govorila tadašnja uprava: »Postoji veliki interes za ulaganje u 'Fotokemiku', ali stranci se boje zbog političke situacije u našoj zemlji. Kod nas u tvornici nekoliko su puta bili Amerikanci želeći da zajedno gradimo tvornicu za proizvodnju floppy diskova i videovrpci. Uložili bi četiri-pet milijuna dolara, ali još čekaju što će se u nas dogoditi« (Kirin i Jolić, 1989: 18). Fotokemika je 1989. i 1990. pokušala realizirati i ugovore o izvozu znanja u Tursku, Egipat i Kolumbiju.

Međutim, hrvatska su se visokotehnološka poduzeća krajem osamdesetih i početkom devedesetih godina bila spremna upustiti u utrku s poduzećima iz kapitalističke jezgre za pozicioniranjem na globalnom tržištu. Jugoslavenska i hrvatska poduzeća spremala su se za jačanje svog utjecaja u zemljama u razvoju, koja su se sve više otvarala, napose u Kini koja se počela otvarati sredinom osamdesetih godina. O strategiji prodora na kinesko tržište svjedoče i dokumenti Republičkog zavoda za međunarodnu znanstveno-tehničku suradnju, koji govore o tržištu »s mnogim specifičnostima, a jedna od tih je činjenica da bez konzistentne politike, stalnog 
prisustva i dugoročne orijentacije nije moguće očekivati povoljne rezultate« (Republički zavod za međunarodnu znanstveno-tehničku suradnju, 1990: 7). No, poduzeća nisu imala mogućnost dugoročne orijentacije, jer su političke promjene ometale proboj u Kinu.

Jedan kazivač tako govori o svojem boravku u Kini sredinom osamdesetih godina u svrhu transfera opreme i tehnologije. No, naglašava kako je zbog masakra na Tiananmenskom trgu 1989., a poslije i zbog raspada Jugoslavije, ugašena svaka suradnja s Kinom (Kazivač 14). Daljnji prodor i zadržavanje na azijskim tržištima, ometali su i ratovi na Bliskom istoku. U Iraku su 1982. usred Iračko-iranskog rata oteta osmorica radnika Đure Đakovića (Brajdić, 2012). Končar se našao u ozbiljnim problemima, jer nije mogao dovršiti unosne poslove u Iraku koji je u ljeto 1990. bio pod međunarodnim sankcijama zbog okupacije Kuvajta. No, čini se da su politički nemiri i ratovi koji su uslijedili na području Jugoslavije zapravo bili ti koji su onemogućili pozicioniranje Hrvatske kao stabilne članice europske poluperiferije i preokrenuli historijsku sekvencu približavanja zemljama jezgre.

\section{Nakon nestanka Istočnog bloka: hrvatska visokotehnološka poduzeća kao lovina (i poneki lovci) u razdoblju tehnoglobalizma}

Treba naglasiti da su se tektonske geopolitičke promjene - nestanak bipolarnog svijeta, raspad Jugoslavije i ratovi koji su uslijedili na tom području - dogodile upravo u vrijeme kad su se događale i bitne promjene u svjetskoj ekonomiji. Geopolitičke su promjene pridonijele raspadu Jugoslavije, jer je s jedne strane nestao Istočni blok i posebno SSSR kao prijetnja koja je održavale kohezivnost multinacionalne Jugoslavije, a s druge je strane jačala privlačnost europske integracije za zapadne republike: Sloveniju i Hrvatsku (Sekulic, 1997). Ekonomska kriza u SSSR-u uslijed njezinog raspada početkom devedesetih godina bila je, pak, snažan udar na izvoz. Osobito se to odnosilo na strojogradnju, čijih je 55\% izvoza išlo u SSSR (Zmijarević, 1991). Poduzeća su pretrpjela dvostruki udar zbog raspada Jugoslavije: nestanak zajedničkoga jugoslavenskog tržišta i nestanak Jugoslavije kao jednog od vodećih aktera Pokreta nesvrstanih, što je potom rezultiralo i slabljenjem veza s tržištima nesvrstanih zemalja. Sigurnosna situacija i neizvjesnost onemogućile su hrvatska poduzeća da odmah pokušaju nastaviti stare veze. Tako je INDAS, što je bilo novo ime Prvomajske, 
tijekom 1990. i 1991. stvorio »kontakte sa Ministarstvom industrije Irana i ponudio projekt za izgradnju Tvornice alata i projekt za modernizaciju metalne industrije. Zbog ratne situacije, predstavnici Irana nisu željeli dolaziti u Zagreb« (Republički zavod za međunarodnu znanstveno-tehničku suradnju, 1992). 1990. pak započinje svjetska kriza u plasmanu alatnih strojeva, jer je prestanak Hladnog rata utjecao na smanjenje proizvodnje naoružanja, što je pogodilo i Prvomajsku (Crneka i Gornik, 2004). Primjer Prvomajske pokazuje koliko egzogeni faktori mogu utjecati na propadanje jednog poduzeća.

Poduzeća koja su se morala prilagođavati geopolitičkim promjenama usto su se našla i usred ekspanzije tehnoglobalizma. Tehnoglobalizam označava promjene prema kojima znanost i tehnologija sve više postaju globalni poduhvat koji više nije u domeni nacionalnih industrijskih šampiona (Reich, 1989). Tehnoglobalizam je jačao od sredine osamdesetih godina 20. stoljeća, a osobito je postao izražen u narednom desetljeću i znatno je utjecao na sudbinu hrvatskih visokotehnoloških poduzeća. Jedan od glavnih indikatora i posljedica tehnoglobalizma bilo je stvaranje globalnih istraživačkih mreža (Howells, 1990), unutar kojih su svoje mjesto tražila i neka od hrvatskih visokotehnoloških poduzeća. No, uključivanje u tehnoglobalizam bilo je puno teže provesti u politički i sigurnosno nestabilnom okruženju tog vremena. S druge strane, Mađarska se, primjerice, uspjela $u$ znatnoj mjeri uključiti u nove trendove i ostvarivala je 30\% mađarskog izvoza 1999. samo zahvaljujući ulasku u multinacionalne mreže Opela (koji je došao u Mađarsku već 1990.), Philipsa, Audija i IBM-a (Berend, 2012).

Neki tipovi industrije i inače su u manjoj mjeri bili uključeni u tehnoglobalističku transformaciju, a i njihovi su proizvodi bili više vezani za specifičan geopolitički položaj Jugoslavije. Najviše su pogođena bila visokotehnološka metaloprerađivačka poduzeća koja su izgubila jugoslavensko i istočnoeuropsko tržište, a njihovo se tržište najčešće otvaralo političkim vezama. Hrvatska je diplomacija tada ponajprije bila usmjerena na međunarodno priznanje Hrvatske i nije se mogla posvetiti gospodarskoj diplomaciji. Metaloprerađivačka industrija je dotad bila zaštićena od konkurencije, a njezin se izvoz subvencionirao (Stipetić, 2013). No, treba reći da je metaloprerađivačku industriju, kao i brodogradnju, u cijeloj Europi znatno pogodio rast konkurencije s Dalekog istoka. Još jedan bitan otežavajući faktor bila je međusobna povezanost tih poduzeća, tako da se 
kriza u jednom poduzeću reflektirala i kod njezinih dobavljača. Poduzeća su prije sudjelovala na zajedničkim projektima ili su oni sa složenijim proizvodima bili kupci dijelova - primjerice, Brodosplit je kupovao turbine od Jugoturbine.

Poduzeća kao što su Željezara Sisak i Jugoturbina našla su se na samoj bojišnici, što je u potpunosti onemogućavalo prilagodbu novom stanju na globalnom tržištu. ${ }^{17}$ Posebno je pogođen bio kombinat Borovo, koji je JNA 1991. razorila te je ostao na okupiranom teritoriju. Kombinaciju negativnih faktora koji su onemogućili transformaciju Borova prema ekonomiji temeljenoj na znanju odlično je opisao kazivač uspoređujući primjer tranzicije Nokije i Borova:

»Naša ulazna sirovina je skuplja od kineskog proizvoda. [...] A ono što su rekli: 'Kako je Nokia narasla iz neke gumarske [...]'. Oni su isto nekad pravili čizme. Gumene čizme je pravila Nokia i sad je [...] Mi nismo bili spremni. Borovo je moglo praviti dobru vojnu cipelu. A pazite, vojnika - koliko ih sad ima? Nemate vi vojsku za ozbiljnu igru. A nekad ih je bilo, koliko ja znam, barem nekih 800 - ako ne i više - hiljada ljudi. Znači, svatko [...]. I ja sam dobivao i potrošio jedan par cipela« (Kazivač 15).

Taj kazivač zapravo opisuje kako se Hrvatska našla u zamci srednjeg dohotka, jer s jedne strane ne može konkurirati jeftinim kineskim proizvodima, što je rezultat premještanja industrijske proizvodnje u zemlje Istočne Azije. S druge strane, Hrvatska nije izvršila punu transformaciju prema ekonomiji znanja kao, primjerice, Finska. Ta transformacija je u Nokiji počela krajem osamdesetih godina kad se ona počela rješavati industrija poput proizvodnje gume koju nije smatrala perspektivnom i do kraja devedesetih se transformirala u svjetskog lidera u mobilnoj telefoniji. Osim obuće, Borovo je također imalo drugu proizvodnju, prvenstveno proizvodnju gume, pa i adaptaciju strojeva za gumarsku i obućarsku industriju. A početkom 1991. u računalnom je centru Borova bilo 200 radnika. Dakle, postojao je određeni potencijal za transformaciju prema ekonomiji znanja, a medijski izvještaji pokazuju da se u to vrijeme intenzivno pregovaralo o novim oblicima suradnje s vodećim svjetskim poduzećima. Među njima i s onima s kojima su već imali intenzivne veze poput Bate i Semperita

${ }^{17}$ Indikativna je usporedba sa Slovenskim železarnama koja je prolazila kroz sanaciju i restrukturiranje u vrijeme kad je Željezara Sisak zbog rata prolazila kroz odsijecanje od ležišta željezne rude u BiH, odljev radne snage od gotovo 5000 ljudi i artiljerijske napade JNA (Malina, 2003). 
(Žekić, 1990). Postoje isključiva ekonometrijska gledišta prema kojima se na osnovu predratne neprofitabilnosti poduzeća kao što su Borovo ili Tvornica lakih metala u Šibeniku na njihova razaranja ne gleda kao na značajan gubitak za hrvatsku ekonomiju (Schönfelder, 2013). Suprotno tomu, ovdje se smatra da su velika poduzeća imala ljudski i brendovski potencijal za transformaciju koji je naglim zaustavljanjem proizvodnje brzo nestajao.

Finska je također svoje približavanje europskoj jezgri nakon Drugoga svjetskog rata temeljila na povoljnom geopolitičkom položaju i ulozi poveznice kapitalističkog Zapada i socijalističkog Istoka (Berend, 2012). No, Finska se, u vrijeme kad je model geopolitičke rente oslabio, nije susrela s razornim geopolitičkim procesima, raspadom države i zajedničkog tržišta te posebno ratom i okupacijom dijelova svojeg teritorija. Već spomenuti faktor militarizirane ekonomije socijalističke Jugoslavije bio je dvostruki udar na novu hrvatsku ekonomiju, a koji se upravo snažno očitovao na slučaju Borova. Militarizirana je ekonomija u početku socijalizma pridonosila rastu BDP-a i inovativnosti nekih od analiziranih poduzeća. No, posebno tijekom raspada Jugoslavije, JNA se pokazala kao loša investicija za hrvatsko društvo. Svojim razarajućim djelovanjem smanjivala je društveni proizvod, a s druge strane je njezin nestanak $u$ vrijeme kad je teško bilo otvarati druga tržišta otkrivao ovisnost poduzeća o vojsci kao kupcu proizvoda.

Hrvatska su se poduzeća našla u teškom tržišnom položaju, jer se Hrvatska nije uspjela uključiti u novi regionalni blok koji bi zamijenio izgubljena istočna tržišta. Poljska, Čehoslovačka i Mađarska već su se 1992. uključile u CEFTA-u, Slovenija 1996., a Hrvatska tek 2003. Ostale zemlje jugoistočne Europe tek su se od 2006. počele uključivati u CEFTA-u, a time se ponovno stvarao poluperiferni hrvatski položaj u postsocijalističkom okružju, no i on je otežan dugotrajnom krizom eurozone. Kompanije iz europske jezgre su, primjerice, proizvodnju opreme za obnovljive izvore energije odmah nakon pada Berlinskog zida »prebacile u Češku, Poljsku, Slovačku. [...] Dakle mi smo se tek nakon tog vala pojavili« (Kazivač 20). Češka, Slovačka i Mađarska, kao jezgra Srednje Europe, trgovinom i investicijama čvrsto su se vezale uz EU jezgru, ponajprije Njemačku, a time se objašnjava i njihovo bolje suočavanje s krizom eurozone nego što je to bilo u južnoj EU periferiji (Galgóczi, 2016). 
Od potencijalnih lovaca u svijetu tehnoglobalizma analizirana su poduzeća uglavnom postajale lovinom zapadnih, ali i poduzeća iz susjednih zemalja. Tako je slovenski proizvođač boja Helios upravo početkom devedesetih godina provodio strategiju širenja i kupnje poduzeća te je postajao lovcem na istočnoeuropske tvornice boje i lakova. 2001. je kupio i Chromos. Jedan od rijetkih hrvatskih lovaca iz ovog istraživanja, uz PLIVU, bila je Podravka, koja je uspjela ostvariti akvizicije u perifernijim zemljama, ali i u zemljama bliže europskoj jezgri. Iz Tablice 4 razvidno je da su analizirana poduzeća doživjela različitu sudbinu kad je riječ o njihovu preživljavanju, ali i usmjerenosti na korištenje znanstvenih resursa u novom društvenom i ekonomskom okruženju. Neka su se poduzeća ili uklopila u globalne kompanije ili nastavile vlastiti razvoj, no mnoga su imala problema u provođenju modernizacije, prilagođavanju novom tržištu i povećanju inovativnosti te su uglavnom izgubila status organizacije s registriranom znanstvenom djelatnošću (čak 14 od 19 poduzeća). Treba naglasiti da je kod očuvanja znanstveno-istraživačke djelatnosti riječ o poduzećima koja su ili dovoljno rano ili dovoljno strukturirano institucionalizirali znanstveno-istraživačku djelatnost, a nisu prolazila kroz naglo i intenzivno dezinvestiranje. Dakako, u poduzećima koja su se susretala s problemima opstanka, intenzivna inovativna djelatnost nije bila u prvom planu i često se promatrala kao trošak. Također, kako su industrijski instituti uglavnom nastajali nakon intenzivnog rasta i širenja poduzeća, često su napuštanjem kombinatskog organiziranja, dezinvestiranjem i smanjenjem broja zaposlenih i u ovim poduzećima industrijski instituti kao zasebne jedinice i znanstvena djelatnost $u$ poduzećima nestajale. ${ }^{18}$ Brojna su dezinvestirana poduzeća danas likvidirana, a u Tablici 4 prikazane su sudbine preostalih poduzeća kako onih koja su sačuvala svoj identitet, tako i onih koja su nastala fragmentiranjem velikih firmi.

\footnotetext{
18 Sličan proces dezintegracije i smanjivanja istraživačko-razvojnog sektora prolazile su i druge postsocijalističke zemlje (Radošević, 1996), no taj je šok, osobito u zemljama koje su već krajem 1997. dobile status kandidata za ulazak u EU (Češka, Mađarska, Slovenija, Poljska i Estonija), bio ublažen dolaskom stranog kapitala ili integracijom u tehnoglobalističke mreže (Hunya, 2000).
} 
Tablica 4. Hrvatska visokotehnološka poduzeća nakon tranzicije: geografska lokacija vlasništva, preuzimanja stranih poduzeća i status znanstvene ustanove

\begin{tabular}{|c|c|c|c|}
\hline poduzeće $e^{19}$ & vlasništvo 2017. godine $e^{20}$ & $\begin{array}{l}\text { preuzimanje } \\
\text { stranih poduzeća } \\
\text { (od } 1990 . \\
\text { godine })^{21}\end{array}$ & $\begin{array}{l}\text { registrirana } \\
\text { znanstveno- } \\
\text { istraživačka } \\
\text { djelatnost } \\
\text { 2017. godine }\end{array}$ \\
\hline 1. CHROMOS & $\begin{array}{l}\text { Poduzeća proizašla iz } \\
\text { kombinata u domaćem } \\
\text { i stranom vlasništvu } \\
\text { (Njemačka, Velika Britanija, } \\
\text { Austrija, Rusija) }\end{array}$ & - & - \\
\hline $\begin{array}{l}\text { 2. PLIVA HRVATSKA } \\
\text { D.O.O. }\end{array}$ & $\begin{array}{l}\text { Poduzeće u stranom } \\
\text { vlasništvu (Izrael); } \\
\text { Dezinvestirana poduzeća } \\
\text { u domaćem i stranom } \\
\text { vlasništvu (Velika Britanija, } \\
\text { Francuska, Belgija, SAD, } \\
\text { Njemačka) }\end{array}$ & $\begin{array}{l}+ \\
\text { Poljska, Slovačka, } \\
\text { Švicarska, } \\
\text { Velika Britanija, } \\
\text { SAD, Francuska, } \\
\text { Danska, } \\
\text { Španjolska }\end{array}$ & + \\
\hline $\begin{array}{l}\text { 3. ĐURO ĐAKOVIĆ } \\
\text { GRUPA D.D. }\end{array}$ & $\begin{array}{l}\text { Holding u domaćem } \\
\text { vlasništvu; } \\
\text { Dezinvestirana poduzeća } \\
\text { u domaćem i stranom } \\
\text { vlasništvu (Italija) }\end{array}$ & - & - \\
\hline $\begin{array}{l}\text { 4. KONČAR - ELEKTRO- } \\
\text { INDUSTRIJA D.D. }\end{array}$ & $\begin{array}{l}\text { Holding u domaćem } \\
\text { vlasništvu; } \\
\text { Dezinvestirana poduzeća } \\
\text { u domaćem i stranom } \\
\text { vlasništvu (Italija, Saudijska } \\
\text { Arabija, Njemačka) }\end{array}$ & $\begin{array}{l}+ \\
\text { Poljska }\end{array}$ & + \\
\hline 5. BRODOSPLIT D.D. & $\begin{array}{l}\text { Grupa u domaćem } \\
\text { vlasništvu; } \\
\text { Dezinvestirano poduzeće u } \\
\text { domaćem vlasništvu }\end{array}$ & - & - \\
\hline 6. BOROVO D.D. & $\begin{array}{l}\text { Poduzeće u domaćem } \\
\text { vlasništvu }\end{array}$ & - & - \\
\hline
\end{tabular}

$\overline{19}$ Poduzećima koja su izgubila svoj identitet ili su smanjena na razinu malih i srednjih poduzeća ostavljeni su nazivi iz socijalističkog razdoblja, a poduzećima koja su donekle sačuvala svoj identitet i ostala su velike tvrtke, stavljeni su današnji nazivi s tipom trgovačkog društva.

20 Podaci su dobiveni iz Sudskog registra Ministarstva pravosuđa Republike Hrvatske i portala Poslovna.hr. U zagradama se nalaze imena zemalja u čijem se vlasništvu nalaze transformirane tvrtke. Geografska lokacija vlasništva dobivena je preko sjedišta poduzeća vlasnika.

${ }^{21}$ Imena zemalja odnose se na sjedište preuzetih poduzeća. 
Nikola Petrović: Hrvatska ekonomija između europske periferije..., Revija za sociologiju 48 (2018), 1: 5-47

\begin{tabular}{|c|c|c|c|}
\hline poduzeće & vlasnišstvo 2017. godine & $\begin{array}{l}\text { preuzimanje } \\
\text { stranih poduzeća } \\
\text { (od } 1990 . \\
\text { godine) }\end{array}$ & $\begin{array}{l}\text { registrirana } \\
\text { znanstveno- } \\
\text { istraživačka } \\
\text { djelatnost } \\
\text { 2017. godine }\end{array}$ \\
\hline 7. ŽELJEZARA SISAK & $\begin{array}{l}\text { Poduzeća proizašla iz } \\
\text { kombinata u domaćem i } \\
\text { stranom vlasništvu (Italija) }\end{array}$ & - & - \\
\hline 8. PRVOMAJSKA & $\begin{array}{l}\text { Dezinvestirana poduzeća } \\
\text { u domaćem i stranom } \\
\text { vlasništvu (Slovenija) }\end{array}$ & - & - \\
\hline 9. PODRAVKA D.D. & $\begin{array}{l}\text { Poduzeće u domaćem } \\
\text { vlasništvu; } \\
\text { Dezinvestirana poduzeća } \\
\text { u domaćem i stranom } \\
\text { vlasništvu (Danska, } \\
\text { Francuska, Češka) }\end{array}$ & $\begin{array}{l}+ \\
\text { Češka, Bosna } \\
\text { i Hercegovina, } \\
\text { Slovenija }\end{array}$ & + \\
\hline 10. FOTOKEMIKA & $\begin{array}{l}\text { Poduzeće u domaćem } \\
\text { vlasništvu }\end{array}$ & - & - \\
\hline 11. RIZ & $\begin{array}{l}\text { Dezinvestirana poduzeća u } \\
\text { domaćem vlasništvu }\end{array}$ & - & - \\
\hline $\begin{array}{l}\text { 12. ERICSSON NIKOLA } \\
\text { TESLA D.D. }\end{array}$ & $\begin{array}{l}\text { Poduzeće u stranom } \\
\text { vlasništvu (Švedska) } \\
\text { Dezinvestirana poduzeća } \\
\text { u domaćem i stranom } \\
\text { vlasništvu (Velika Britanija, } \\
\text { Nizozemska) }\end{array}$ & - & + \\
\hline 13. JUGOTURBINA & $\begin{array}{l}\text { Dezinvestirana poduzeća } \\
\text { u domaćem i stranom } \\
\text { vlasništvu (SAD) }\end{array}$ & - & - \\
\hline 14. INA D.D. & $\begin{array}{l}\text { Poduzeće u stranom } \\
\text { vlasništvu (Mađarska) } \\
\text { Dezinvestirana poduzeća } \\
\text { u domaćem vlasništvu } \\
\text { i stranom vlasništvu } \\
\text { (Slovenija) }\end{array}$ & - & + \\
\hline 15. BELJE D.D. & $\begin{array}{l}\text { Poduzeće u domaćem } \\
\text { vlasništvu }\end{array}$ & - & - \\
\hline 16. IPK OSIJEK & $\begin{array}{l}\text { Poduzeća proizašla iz } \\
\text { kombinata u domaćem } \\
\text { i stranom vlasništvu } \\
\text { (Njemačka, SAD, Bosna i } \\
\text { Hercegovina) }\end{array}$ & - & - \\
\hline
\end{tabular}

$\overline{22}$ Prisutnost stranoga švedskog kapitala iznosi $49 \%$, dok ostali dioničari imaju osjetno manje udjele.

${ }^{23}$ Prisutnost stranoga mađarskog kapitala iznosi $49 \%$, no mađarska strana ima upravljačka prava. 


\begin{tabular}{llll}
\hline poduzeće & vlasništvo 2017. godine & $\begin{array}{l}\text { preuzimanje } \\
\text { stranih poduzeća } \\
\text { (od 1990. }\end{array}$ & $\begin{array}{l}\text { registrirana } \\
\text { znanstveno- } \\
\text { istraživačka } \\
\text { djelatnost } \\
\text { 2017. godine }\end{array}$ \\
\hline 17. KOKA D.D. & $\begin{array}{l}\text { Poduzeće u domaćem } \\
\text { vlasništvu }\end{array}$ & - \\
\hline 18. ATM & $\begin{array}{l}\text { Poduzeća u domaćem } \\
\text { i stranom vlasništvu } \\
\text { (Njemačka) }\end{array}$ & - \\
\hline 19. PK ZADAR & $\begin{array}{l}\text { Poduzeća u domaćem } \\
\text { vlasništvu i stranom } \\
\text { vlasništvu (SAD) }\end{array}$ & - & - \\
\hline
\end{tabular}

Prijašnja povezanost s poduzećima koja su postajala glavni akteri svjetskog tehnoglobalizma omogućila je pak nekim poduzećima da se uključe u nove ekonomske konstelacije. Tesla je tako 1995. postala dio Ericssonove multinacionalne mreže te je postupno napustila fizičku proizvodnju i preusmjerila se na razvoj softvera, a osim ruskog tržišta otvorila su joj se i bjelorusko i kosovsko te druga perifernija tržišta. Siemens je 1995. preuzeo ATM, s kojim je od 1975. imao ugovor o dugoročnoj proizvodnoj kooperaciji (Anić, 2011). ${ }^{24}$ Sličan proces prolazila su i neka manja poduzeća koja su nastala napuštanjem kombinatskog načina organiziranja, a nastavila su svoj život unutar stranih poduzeća. Primjerice, Chromosovu proizvodnju aroma preuzelo je 1993. njemačko poduzeće s kojim su surađivali od kraja sedamdesetih godina. Proizvodnju kombajna Đure Đakovića preuzeo je 2005. talijanski koncern koji je pak kupio njemačkog proizvođača traktora s kojim je Đaković početkom osamdesetih godina potpisao ugovor o dugoročnoj suradnji. PLIVIN istraživački institut preuzeo je 2006. GlaxoSmithKlein, s kojim su od početka 21. stoljeća imali suradnju na otkrivanju novog antibiotika. Ti primjeri pokazuju zakašnjelost stranih direktnih investicija koje su se intenzivirale tek nakon završetka Domovinskog rata (Kersan-Škabić i Zubin, 2009).

Privatizacija ostatka PLIVE pokazuje pak vrlo zanimljiv primjer složenog odnosa geopolitike i ekonomske globalizacije. PLIVU je 2006. kupio američki Barr, a dokumenti koje je otkrio Wikileaks govore o utjecaju

24 Treba podsjetiti da je taj slučaj bio posebno kontroverzan, jer je Siemens optuživan da je, kao i u brojnim domaćim tajkunskim privatizacijama, bio ponajprije zainteresiran za nekretninu ATM-a. Tomu svjedoči podatak da su gotovi svi radnici iz pogona otpušteni (Marić, 1999). 
američkog veleposlanstva na Vladu Republike Hrvatske kako bi PLIVA bila prodana Barru, nasuprot islandskom Actavisu koji je, navodno, imao veze s ruskim kapitalom. ${ }^{25} \mathrm{No}$, ti su se politički pritisci s pozicije američke nacionalne ekonomije pokazali prilično uzaludnima, jer su se već 2008. Barr, a unutar njega i PLIVA, našli unutar farmaceutskog diva Teva sa sjedištem u Izraelu. Zanimljivo je da je kroz neko vrijeme i Actavis preko akvizicije i spajanja izgubio svaki islandski predznak, a da se od 2016. i dijelovi Actavisa koji se bave proizvodnjom generičkih lijekova nalaze unutar Tevinoga farmaceutskog carstva. U razdoblju tehnoglobalizma intenzivno širenje multinacionalnih kompanija može brzo nadići geopolitičke odluke, što se jasno vidjelo na primjeru Hrvatske. ${ }^{26}$

U hrvatskoj su javnosti tehnoglobalistički procesi bili promatrani ponajprije kroz prizmu rasprodaje obiteljskog srebra i slučajeva korupcije koji se vezuju uz velike privatizacije. Osobito se to odnosilo na slučaj privatizacije PLIVE, koji je za hrvatsku javnost bio posebno traumatičan. Ponajprije zato što je PLIVA do Barrova preuzimanja bila jedna od rijetkih hrvatskih kompanija koja se mogla smatrati tehnoglobalističkim lovcem. PLIVA je sredinom devedesetih godina bila u intenzivnom tehnoglobalističkom pohodu. Nakon izlaska na londonsku burzu 1996. ona zapravo postaje međunarodnom kompanijom. Imala je nekoliko istraživačkih centara izvan nacionalnih granica, od Indije do SAD-a, pa se to razdoblje opisuje kao »velika ekspanzija« (Kazivač 5). No, u hrvatskom je medijskom prostoru sudbina PLIVE ponajprije gledana kroz utjecaj ortačkog kapitalizma simboliziranog u aferi Verona (tajni sastanak hrvatskog premijera Ive Sanadera i predsjednika uprave PLIVE Željka Čovića), a nedovoljno kroz međuigru geopolitike i tehnoglobalizma. ${ }^{27}$ Tehnoglobalizam je bio osobito utjecajan $u$

\footnotetext{
${ }^{25}$ https://wikileaks.org/plusd/cables/06ZAGREB815_a.html.

${ }^{26}$ Slična se izmjena geopolitičke odluke dogodila i u slučaju Karlovačke pivovare koja je 1994. ušla u vlasništvo obitelji Lukšić, a 2003. postaje dijelom multinacionalne kompanije Heineken. Taj je slučaj na zanimljiv način analiziran kroz sukob različitih upravljačkih kultura (Topolčić, 2007). No, prva odluka je bila geopolitička odluka u sklopu kampanje privlačenja kapitala hrvatske dijaspore na početku devedesetih godina koju je promovirao Franjo Tuđman, a konačno je rješenje rezultat konsolidacije svjetske pivarske industrije na nekolicinu dominantnih igrača.

27 Usporedba povijesti PLIVE s Gedeon Richterom, multinacionalnom farmaceutskom kompanijom sa sjedištem u Budimpešti, prikladna je za usporedbu ovdje prikazanih utjecaja geopolitičkih događaja na razvoj poduzeća i važnosti pravovremenog pozicioniranja na svjetskom tržištu. Gedeon Richter osnovan je 1901., a u međuratnom je razdoblju bio jedan od prvih europskih proizvođača inzulina i imao je predstavnike na svim kontinen-
} 
farmaceutskoj industriji zbog specifičnosti njezinoga istraživanja i razvoja koje omogućuje visok stupanj mobilnosti i suradnje. Sljedeći citat pokazuje kako to izgleda u PLIVI kao dijelu multinacionalne korporacije:

»Nama se otvaraju laboratoriji u Americi, u Izraelu, u Engleskoj, u Njemačkoj. [...] Gdje god je potreba. [...] Istraživači odlaze tamo na neko vrijeme, znači rade u tim laboratorijima. Iz tih drugih zemalja dolaze ovdje. [...] Bilo da su prošli jednu fazu edukacije kod nas, bilo da su donijeli svoju problematiku ovdje i onda su zajedno sa našim ljudima rješavali njihove probleme« (Kazivač 10).

Današnje stanje u PLIVINOM ili Ericsson Nikola Tesla istraživanju i razvoju preslika je tehnoglobalističkog ideala. Ispunjavanje Kopenhaških kriterija o funkcionalnoj tržišnoj ekonomiji, priključenje Hrvatske Europskoj uniji i jedinstvenom tržištu, ubrzalo je i dalje ubrzava procese tehnoglobalizma u hrvatskim poduzećima i jačanje veza sa zemljama europske jezgre. No, ti su procesi uzrokovali ugrožavanje nekih poduzeća zbog pritiska na privatizaciju nedovoljno restrukturiranih poduzeća i povećanja konkurencije sa Zapada. Ipak, predviđanje potpune dominacije ekonomske globalizacije može se pokazati naivnim kao što se pokazala naivnom i Fukuyamina vizija o kraju povijesti kroz pobjedu liberalne demokracije (Fukuyama, 1992). Hrvatska visokotehnološka poduzeća osjetila su to već s ratom u Siriji i gubljenjem INA-inih naftnih polja u toj zemlji. Da ekonomska liberalizacija i prevladavanje ekonomskih nad geopolitičkim odlukama nije ireverzibilan proces, pokazao je i rat u Ukrajini 2014. Nova geopolitička preslagivanja utjecala su na ekonomske promjene. Simbolično je da je gašenju proizvodnje u Željezari Sisak, koja je nastupilo usred priprema za Drugi svjetski rat, presudio rat u Ukrajini. Jeftino je ukrajinsko željezo zbog sukoba završilo u Europi umjesto na svojem uobičajenom ruskom tržištu. To je dovelo do toga da je, ionako već znatno reducirana, proizvodnja u Sisku postala neisplativom i ugašena je krajem 2015. To je zaoštravanje ugrozilo izvoz mnogih poduzeća u Rusiju (ponovno je tu bio i Ericsson Nikola Tesla) i dalo je novo geopolitičko značenje hrvatskoj ekonomiji, što

tima te tvrtke kćeri u Zapadnoj Europi. U vrijeme socijalizma izgubio je i tvrtke kćeri i tržišta Zapadne Europe. Šezdesetih godina 20. stoljeća postiže znatan uspjeh na sovjetskom tržištu, a sedamdesetih, nakon liberalizacije mađarskog socijalizma, vraća se na tržišta Zapada. Na već spomenutoj rang listi broja američkih patenata u srednjoeuropskim organizacijama nalazi se na drugom mjestu (Radosevic, 1999). Početkom devedesetih godina proveo je restrukturiranje, a na budimpeštansku burzu izišao je 1994. te je danas utjecajan globalni igrač. 
se očituje, primjerice, kroz najavu izgradnje terminala za ukapljeni prirodni plin na Krku, licitiranje Rusije i SAD-a oko kupovine INA-e i rješavanja slučaja Agrokor.

\section{Zaključak}

Nastanak, razvoj, pa i nestanak, hrvatskih visokotehnoloških poduzeća upućuje na to da su kontingentni povijesni događaji imali deterministička svojstva za mnoga od njih. Lanac događaja koji je počeo s Prvim svjetskim ratom znatno je pridonio nastanku hrvatske visokotehnološke industrije, jer je strani kapital želio pristup novom tržištu zaštićenom visokim carinama. Zanimljiva je činjenica da je nasuprot, za hrvatske krajeve nepovoljnoj, unitarističkoj ekonomskoj politici, strani kapital potaknuo stvaranje hrvatske industrije. Već to razdoblje upućuje na potencijalno veću važnost egzogenih faktora na razvoj industrije jedne male države od nepovoljnog djelovanja unutarnjih aktera.

Drugi svjetski rat je pak omogućio rast nekih industrija vezanih uz ratnu ekonomiju, a ishod rata odredio je novu geopolitičku podjelu Europe. Raskid s SSSR-om potaknuo je novi lanac događaja koji je rezultirao specifičnim geopolitičkim položajem socijalističke Jugoslavije. Taj je položaj hrvatskim poduzećima omogućivao brže približavanje jezgri u odnosu na poduzeća iz drugih socijalističkih zemalja Srednje Europe. I država i ovdje analizirana poduzeća u tom su razdoblju uspjele izboriti povoljan poluperiferni status unutar modernoga svjetskog sistema. Raspad Istočnog bloka stvorio je lanac događaja nakon kojih se Hrvatska našla u lošijem geopolitičkom i geoekonomskom položaju od većine ostalih postsocijalističkih država. Ratna razaranja, okupacija dijelova Hrvatske, a nakon toga i njezina međunarodna izolacija usporile su ulazak u EU i onemogućivala poduzeća u transformaciji i snažnijem rastu i ekspanziji ili privlačenju stranog kapitala, upravo u trenutku kad su se događale bitne promjene $\mathrm{u}$ svjetskoj ekonomiji. No, neka su se visokotehnološka poduzeća ili uspjela uključiti u tehnoglobalističke mreže ili nastavile samostalan razvoj. Novi geopolitički izazovi i njihov utjecaj na analizirana poduzeća pokazuju da bi kontingentni događaji i geopolitičke promjene još uvijek mogle bitno utjecati na hrvatsku ekonomiju.

Nasuprot Wallersteinovoj teoriji modernoga svjetskog sistema, koja naglašava eksploatatorsku ulogu Zapada, hrvatski slučaj upućuje na to da države mogu, zbog posljedica nepredviđenih događaja, prilično brzo pro- 
mijeniti dugotrajne odnose koji su uspostavljeni ranijom industrijalizacijom, ali također i brzo izgubiti novostečene pozicije. Istraživanje povijesti hrvatskih visokotehnoloških poduzeća upućuje na važnost kontingentnih događaja i geopolitičkog položaja u određivanju ekonomskog smjera i uspjeha nekog područja. Socijalistička Jugoslavija postala je utjecajan poluperiferni akter ponajprije zbog kontingentnih događaja, a također i nove države nastale njezinim raspadom zbog različitih kontingentnih događaja u većoj su ili manjoj mjeri izgubile taj status. Povoljnije geopolitičke okolnosti omogućile su, primjerice Sloveniji, da djelomično zadrži svoj važan poluperiferni status, a njezinim poduzećima da preuzimaju i osnivaju poduzeća ponajviše na europskom jugoistoku, ali i na Zapadu i Kini (Jaklič i Svetličič, 2011). Mahoneyjevo upozorenje o važnosti događaja koji se odvijaju u ranim etapama historijske sekvence čini se vrlo bitnim za razumijevanje položaja hrvatske ekonomije u svjetskom sistemu. Geopolitičko približavanje Jugoslavije Zapadu nakon 1948. događalo se na samom početku razdoblja poslijeratnog uzleta i kapitalističkih i socijalističkih europskih ekonomija poznatog pod nazivom »trideset slavnih godina« (Fourastié, 1979), a to je omogućilo i ekspanziju hrvatskih visokotehnoloških poduzeća i ekonomije. Rumunjsko približavanje Zapadu i mađarski reformistički »gulaš-socijalizam« dogodili su se pri kraju tog razdoblja, sredinom šezdesetih godina.

Slično, ali sa suprotnim učinkom, događaji nasilnog raspada Jugoslavije odvijali su se na samom početku intenziviranja tehnoglobalizma. Srednjoeuropski konkurenti imali su prednost ili u privlačenju stranog kapitala, koji je kao u slučaju Mađarske razvijao mađarske i proizvodne i istraživačko-razvojne kapacitete, ili u vremenu za konsolidaciju svojih nacionalnih šampiona, kao u slučaju Slovenije čije je Gorenje postalo tehnoglobalističkim lovcem. Događaji s početka devedesetih godina imaju dugoročne posljedice, jer su rezultirali kasnijim priključenjem Hrvatske Europskoj uniji, a to je opet omogućivalo većini postsocijalističkih zemalja i njihovim poduzećima da se s boljim startnim pozicijama uključe $\mathrm{u}$ jedinstveno europsko tržište, kao u slučaju intenzivnog premještanja automobilske proizvodnje na periferiju EU-a. Kao što je Wallerstein ustvrdio, značajna preobrazba ranga države u svjetskoj podjeli rada nakon takvih značajnih promjena u manjoj mjeri ovisi o državnoj politici, jer uspjeh jedne države smanjuje prilike ostalih. Sporija integracija ostalih jugoslavenskih postsocijalističkih država u suvremene ekonomske tokove, također zbog događaja kao što je Rat na 
Kosovu, nije dozvoljavala Hrvatskoj da brže ponovno uspostavi i iskoristi svoj poluperiferni položaj.

Na kraju je potrebno navesti ograničenja ove studije i preporuke za daljnja istraživanja. Odabir poduzeća koja su imala registriranu znanstvenu djelatnost krajem osamdesetih godina može upućivati na određenu selekcijsku pristranost, jer ta su poduzeća zbog svoje veličine i utjecaja bila više uključena u svjetske tokove i pod većim utjecajem geopolitičkih promjena. U sljedećim istraživanjima bi trebalo analizirati i geopolitičke utjecaje i na mala i srednja hrvatska poduzeća. Drugo ograničenje istraživanja odnosi se na korištenje događajne sociologije i ovisnosti o prijeđenom putu u analizi razvoja hrvatske industrije, jer te teorije mogu pretjerano naglasiti utjecaj nepredviđenih događaja, a zanemariti ulogu struktura dugog trajanja, poput slabije razvijenosti tržišta i poduzetničke kulture u usporedbi s krajevima gdje je industrijalizacija počela ranije. Zbog toga se ne odbacuje Wallersteinov moderni svjetski sistem čiji je nastanak smješten u vrijeme kad su se hrvatski krajevi nalazili u nepovoljnim geopolitičkim uvjetima. Ti uvjeti dugo nisu dopuštali sustavno uključivanje u modernu svjetsku ekonomiju, a to je ostavilo traga na daljnje faze razvoja. To je ograničenje na tragu jedne važne zamjerke i Sewellu i Mahoneyju, koji ne razrađuju dovoljno skokove natrag u povijest (Tang, 2013), kao što je povratak Hrvatske na stari položaj u svjetskoj podjeli rada.

Također, naglasak na egzogenim uzrocima može dovesti do zanemarivanje značajne uloge institucija i individualnih aktera. Dakako, u vremenima manje opterećenim povijesnim događajima do većeg izražaja dolazi djelovanje hrvatskih upravljačkih i ekonomskih elita. Ipak i tu treba uzeti u obzir to da je njihova struktura i djelovanje pod utjecajem povijesnih događaja, napose različitih prevrata koji su tijekom cijeloga 20. stoljeća rezultirali odbacivanjem nepodobnih elita i nemogućnošću promišljanja ekonomskog razvoja, a taj proces može indicirati i određeni cirkularni kauzalitet (Tang, 2013). Primjerice, elita ponajprije opterećena stjecanjem hrvatske nezavisnosti i međunarodnog priznanja omogućila je koruptivnu privatizaciju i zanemarivala pozicioniranje hrvatskih poduzeća u novim svjetskim tokovima.

No, prošlo je stoljeće prije svega bilo razdoblje snažnih i naglih geopolitičkih promjena, koje su vjerojatno ostavile ozbiljan trag ne samo na položaj hrvatske ekonomije, nego i na samopercepciju hrvatskog položaja u modernom svjetskom sustavu. Jugoslavenska socijalistička posebnost, koja 
je bila kratkog vijeka, u novije vrijeme vjerojatno utječe na samopercepciju posebne hrvatske zaostalosti, koja se može promatrati i kao povratak Hrvatske na njezin tradicionalan položaj na granicu europske poluperiferije i periferije.

Povijest razvoja i nastanka ovdje analiziranih poduzeća indicira da kontingenti događaji i geopolitičke promjene mogu znatno utjecati na razvoj nacionalne ekonomije. Proučavanje utjecaja geopolitičkih prilika na razvoj poduzeća i ekonomski rast svakako zahtijevaju i detaljnije studije slučajeva i ekstenzivnije komparativne analize koje će uključivati više hrvatskih poduzeća, ali i primjere iz drugih zemalja. No, daljnja su istraživanja svakako potrebna ako se želi nadopuniti sociološka objašnjenja razvoja hrvatske ekonomije koja se usmjeravaju na ideološke, kulturne i unutarnjopolitičke faktore.

\section{LITERATURA}

Anić, Tomislav (2011). Povijest obilježena inovacijama: 125 godina Siemensa u Hrvatskoj. Zagreb: Siemens i Hrvatski institut za povijest.

Badovinac, Tomislav (ur.) (2004). Zagreb i Hrvatska u Titovo doba. Zagreb: Savez društava »Josip Broz Tito« Hrvatske.

Bahtijari, Snježana (ur.) (2009). 60 godina Ericsson Nikola Tesla. Zagreb: Ericsson Nikola Tesla.

Bartl, Zlata i Vucelić, Zlata (1983). »Kratak prikaz tehnološkog razvoja 'Podravke' od 1947. do 1957. godine«, Podravka, 1 (1): 57-63.

Belamarić, Igor (2009). Brodosplit u Supavalskoj uvali. Split: Književni krug Split i Knjižara Morpurgo.

Belošić, Željko (ur.) (2002). INA NAFTAPLIN 1952.-2002. Zagreb: INA.

Benoit, Emile (1978). »Growth and defense in developing countries«, Economic development and cultural change, 26 (2): 271-280. doi: 10.1086/451015

Berend, Ivan T. (2012). Ekonomska povijest Europe dvadesetog stoljeća. Zagreb: Mate.

Berend, Ivan T. i Ránki, György (1996). Evropska periferija i industrijalizacija 1780-1914. Zagreb: Naprijed.

Bilandžić, Dušan (1969). Borba za samoupravni socijalizam u Jugoslaviji 19451969. Zagreb: Institut za historiju radničkog pokreta Hrvatske.

Bilandžić, Dušan (1985). Historija Socijalističke Federativne Republike Jugoslavije: glavni procesi 1918-1985. Zagreb: Školska knjiga.

Bogetić, Dragan (2010). »Jugoslavija i svetsko tržište kapitala: američka finansijska podrška jugoslovenskim razvojnim programima krajem 50-tih godina« Tokovi istorije, 44 (3): 89-102.

Brajdić, Danijel (ur.) (2012). Industrija »Đuro Đaković«: 90 godina strojogradnje u Slavonskom Brodu. Slavonski Brod: Đuro Đaković Holding. 
Butković, Mirko (2005). Jugoturbina: nastanak, razvoj i kraj (1949.-1992.). Karlovac: Veleučilište.

Car, Stjepan (2011). KONČAR - Institut za elektrotehniku: 50 godina primijenjenih znanstvenih istraživanja i razvoja na području elektrotehnike. Zagreb: KONČAR - Institut za elektrotehniku d.d.

Chromos (1970). Chromos: 50 godina ustrajnog rada i uspjeha. Zagreb: Kemijski kombinat CHROMOS-KATRAN-KUTRILIN.

Crneka, Antun i Gornik, Boris (2004). »PRVOMAJSKA (razvoj tvornice alatnih strojeva)«, u: Tomislav Badovinac (ur.). Zagreb i Hrvatska u Titovo doba. Zagreb: Savez društava »Josip Broz Tito« Hrvatske, str. 173-178.

Čengić, Drago, Družić, Gordan, Komar, Zoran i Stamenić, Zoran (1991). Inovacijski subsistem i njegova okolina. Zagreb: Institut za društvena istraživanja Sveučilišta u Zagrebu.

Čengić, Drago, Komar, Zoran i Kraljeta, Vedran (1990). Kraj inovacijske iluzije? Društveni okviri tehnološkog stvaralaštva. Zagreb: Radna zajednica Republičke konferencije Saveza socijalističke omladine Hrvatske.

Čepo, Zlatko (1974). Željezara Sisak 1938-1973. Sisak : Metalurški kombinat Željezare Sisak.

Dekanić, Igor (1990). »Svjetsko tržište nafte 90-ih godina«, Nafta 41 (7-8): 357369.

Doljak, Marijan (1955). »1955.«, Fotokemijska industrija, 2 (4): 36.

Duić-Dunja, Ante (2005). Borovo: od trnja do zvijezda i natrag. Vukovar: Borovo i Zagreb: Školska knjiga.

Đekić, Velid (2012). »Rafinerija nafte Rijeka-europski pionir u preradi crnog zlata«, Povijest u nastavi, 8 (15): 113-128.

Fourastié, Jean (1979). Les Trente Glorieuses: Ou la révolution invisible de 1946 à 1975. Paris: Fayard.

Franičević, Vojmir (2002). »Politička i moralna ekonomija u prvom desetljeću tranzicije u Hrvatskoj«, Politička misao, 39 (1): 3-34.

Fukuyama, Francis (1992). The End of History and the Last Man. New York: Free Press.

Galgóczi, Béla (2016). »The southern and eastern peripheries of Europe: Is convergence a lost cause?«, u: José Magone, Brigid Laffan i Christian Schweiger (ur.). Core-periphery relations in the European Union. Abingdon: Routledge, str. 130-147.

Gradsko poglavarstvo Zagreb (1942). Braća Ševčik. Tvornica strojeva i ljevaonica metala. 1. Organizacija poslovanja i upravljanje 1922-1947. Zagreb: Gradsko poglavarstvo Zagreb.

Griffin, Larry J. (1992). »Temporality, events, and explanation in historical sociology: An introduction«, Sociological Methods \& Research, 20 (4): 403-427. doi: $10.1177 / 0049124192020004001$

Howells, Jeremy (1990). »The internationalization of R \& D and the development of global research networks«, Regional Studies, 24 (6): 495-512. doi: $10.1080 / 00343409012331346174$

Hunya, Gábor (2000). International Competitiveness Impacts of FDI in CEECs. Wien: Wiener Institut für Internationale Wirtschaftsvergleiche. 
Iveljić, Iskra (2007). Očevi i sinovi: privredna elita Zagreba u drugoj polovici 19. stoljeća. Zagreb: Leykam International.

Jaklič, Andreja i Svetličič, Marjan (2011). »Multinationals from Slovenia: Nano size, but giga important«, u: Louis Brennan (ur.). The Emergence of Southern Multinationals: Their Impact on Europe. Basingstoke: Palgrave Macmillan, str.130-148.

Jakovina, Tvrtko (2002). Socijalizam na američkoj pšenici. Zagreb: Matica hrvatska.

Jakovina, Tvrtko (2003). Američki komunistički saveznik: Hrvati, Titova Jugoslavija i Sjedinjene Američke Države, 1945.-1955. Zagreb: Profil.

Jakovina, Tvrtko (2010). »Najvažniji događaj od kapitulacije Japana«, tportal.hr, 23. svibnja. https://www.tportal.hr/vijesti/clanak/najvazniji-dogadaj-od-kapitulacije-japana-20100522/print.

Karaman, Igor (1991). Industrijalizacija građanske Hrvatske (1800-1941). Zagreb: Naprijed.

Kersan-Škabić, Ines i Zubin, Cinzia (2009). »Utjecaj izravnih inozemnih ulaganja na rast BDP, na zaposlenost i na izvoz u Hrvatskoj«, Ekonomski pregled, 60 (3-4): 119-151.

Kirin, Drago i Jolić, Stipe (1989). »Stranci se boje ulagati«, Večernji list, 16. kolovoza, str. 18.

Kolar-Dimitrijević, Mira (1990). »Strani kapital i Banovina Hrvatska 1939.-1941.«, Povijesni prilozi, 9 (9): 165-194.

Kolar-Dimitrijević, Mira (1998). »Belje između dva svjetska rata: uloga politike u organizaciji beljskog gospodarstva od 1918. do 1941. godine«, Časopis za suvremenu povijest, 30 (3): 507-525.

Kovačević, Gordana (2009). »Aktivno sudjelovanje u kreiranju novih tehnoloških trendova«, u Snježana Bahtijari (ur.). 60 godina Ericsson Nikola Tesla. Zagreb: Ericsson Nikola Tesla, str. 41-49.

Lampe, John, Prickett, Russell i Adamovic, Ljubisa (1990). Yugoslav-American Economic Relations Since World War II. Durham: Duke University Press.

Mahoney, James (2000). »Path dependence in historical sociology«, Theory and society, 29 (4): 507-548.

Malina, Marijan (2003). »Tranzicija u Željezari Sisak«, Metalurgija, 42 (1): 69-73.

Marić, Jagoda (1999). »Za šutnju 15 tisuća kuna«, Novi list, 8. siječnja, str. 15.

Mihaljević, Domagoj (2013). »The deindustrialisation process of the Croatian economy«, Kurswechsel, 14 (3): 63-73.

Mileta, Vlatko (1986). »Ekonomski odnosi Jugoslavije sa zemljama u razvoju«, Politička misao, 23 (3): 51-57.

Ožanić, Marijan (2016). »Tomo Bosanac - Otac generatora«, Sve o poduzetništvu, 23. siječnja. http://www.sveopoduzetnistvu.com/index.php?main=clanak\&id=81.

Petrović, Nikola (2008). »Agrokor: između političkog kapitalizma i ekonomskog liberalizma«, u: Drago Čengić (ur.). Kapitalizam i socijalna integracija. Zagreb: Institut društvenih znanosti Ivo Pilar, str. 89-111.

Rade Končar (1981). Rade Končar: industrijska elektronika. Zagreb: Rade Končar.

Radošević, Slavo (1991). Uvod u tehnološku politiku Jugoslavije. Zagreb: Ekonomski institut. 
Radosevic, Slavo (1994). »The generic problems of competitiveness at company level in the former socialist economies: The case of Croatia«, Europe-Asia Studies, 46 (3): 489-503. doi: 10.1080/09668139408412174

Radosevic, Slavo (1996). »Restructuring of R\&D institutes in post-socialist economies: Emerging patterns and issues«, u Andrew Webster (ur.). Building New Bases for Innovation: The Transformation of the R\&D System in Post-Socialist States. Cambridge: Anglia Polytechnic University, str. 8-30.

Radosevic, Slavo (1999). »Technological 'catching-up' potential of Central and Eastern Europe: an Analysis based on US foreign patenting data«, Technology Analysis \& Strategic Management, 11 (1): 95-111. doi: 10.1080/095373299107609

Reich, Robert B. (1989). The Resurgent Liberal and Other Unfashionable Prophecies. New York: Times Books.

Republički zavod za međunarodnu znanstveno-tehničku suradnju (1990). Informacije o suradnji SFRJ s NR Kinom. Zagreb: Republički zavod za međunarodnu znanstveno-tehničku suradnju.

Republički zavod za međunarodnu znanstveno-tehničku suradnju (1992). Republika Hrvatska. Zagreb: Republički zavod za međunarodnu znanstveno-tehničku suradnju.

Rivero, Douglas (2012). The Détente Deception: Soviet and Western Bloc Competition and the Subversion of Cold War Peace. Lanham: University Press of America.

Rogić, Ivan (2000). Tehnika i samostalnost: okvir za sliku treće hrvatske modernizacije. Zagreb: Hrvatska sveučilišna naklada.

Schönfelder, Bruno (2013). »Utjecaj rata na gospodarstvo«, u: Reneo Lukić, Sabrina P. Ramet i Konrad Clewing (ur.). Hrvatska od osamostaljenja: rat, politika, društvo, vanjski odnosi. Zagreb: Golden marketing i Tehnička knjiga, str. 201-223.

Sekulic, Dusko (1997). » The Creation and Dissolution of the Multinational State: The Case of Yugoslavia«, Nations and Nationalism, 3 (2): 165-179. doi: 10.1111/j.1354-5078.1997.00165.x

Sewell, William H. Jr. (2005). Logics of history: Social theory and social transformation. Chicago: University of Chicago Press.

Sirotković, Jakov (2000). »Teorijske, analitičke i institucionalne pretpostavke dugoročne strategije gospodarskog razvoja Hrvatske«, u Gordan Družić i Jakov Sirotković (ur.). Uvjeti i izgledi ekonomskog razvoja Hrvatske početkom 21. stoljeća. Zagreb: HAZU, str. 9-41.

Stančić, Nikša (2002). Hrvatska nacija i hrvatski nacionalizam u 19. i 20. stoljeću. Zagreb: Barbat.

Steindorff, Ludwig (2006). Povijest Hrvatske: od srednjeg vijeka do danas. Zagreb: Naklada Jesenski i Turk i Institut društvenih znanosti Ivo Pilar.

Stipetić, Vladimir (2012). Dva stoljeća hrvatskoga gospodarstva (1820.-2005.). Zagreb: HAZU.

Stipetić, Vladimir (2013). Hrvatsko gospodarstvo: okruženje, naslijeđe i prijetnje, nade i mogućnosti. Zagreb: HAZU.

Šćrbačić, Mira (1981). PLIVA: 50 godina. Zagreb: Pliva. 
Škrgatić, Dragutin i Mandić, Zlatko (ur.) (1960). Rade Končar: petnaest godina poduzeća i deset godina radničkog upravljanja. Zagreb: Rade Končar.

Švarc, Jadranka (2009). Hrvatska u društvu znanja: prijepori i perspektive inovacijske politike. Zagreb: Školska knjiga i Institut društvenih znanosti Ivo Pilar.

Tang, Chih-Chieh (2013). »Toward a really temporalized theory of event: A Luhmannian critique and reconstruction of Sewell's logics of history«, Social Science Information, 52 (1): 34-61. doi: 10.1177/0539018412466633

Topolčić, Davor (2007). »Studija slučaja 'susreta kultura': Hrvatska pivovara u vlasništvu stranih ulagača«, Društvena istraživanja, 16 (4-5): 677-700.

Tsakaloyannis, Panos (1981). »The politics and economics of EEC-Yugoslav relations«, Journal of European Integration, 5 (1): 29-52. doi: 10.1080/07036338108428808

Volner, Hrvoje (2012). »Nastanak i političko-upravni odnosi u općini Belišće u razdoblju Kraljevine Srba, Hrvata i Slovenaca«, Scrinia Slavonica, 12 (1): 179-204.

Vučinić, Mihajlo, Nikezić, Ilija i Todorović, Boško (1989). Koncepcija, doktrina i sistem opštenarodne odbrane. Beograd: Vojnoizdavački i novinski centar.

Vuković, Vuk, Štulhofer, Aleksandar i Burić Ivan (2017). »Je li Županov imao pravo? Testiranje podrijetla i perzistencije egalitarnoga sindroma«, Društvena istraživanja, 26 (2): 207-225. doi: 10.5559/di.26.2.04

Wallerstein, Immanuel (1986 [1974, 1980]). Suvremeni svjetski sistem. Zagreb: Centar za kulturnu djelatnost.

Wallerstein, Immanuel (1991). Geopolitics and geoculture: Essays on the changing world-system. Cambridge: Cambridge University Press.

Woodward, Susan (1995). Balkan Tragedy: Chaos and Dissolution After the Cold War. Washington: Brookings Institution Press.

Zmijarević, Davorka (1991). »Ima li nade za izvoznike?«, Zapad, 10. lipnja.

Žebec Šilj, Ivana (2017). Zagrebačka industrija 1935.-1939. u kontekstu međuratnog gospodarskog razvoja. Zagreb: Institut društvenih znanosti Ivo Pilar.

Žekić, Kamenko (1990). »Partneri za izvozni ples«, Večernji list, 3. siječnja.

Županov, Josip (1995). Poslije potopa. Zagreb: Nakladni zavod Globus.

Županov, Josip (1998). »Politika pritisaka kao ideal: tipski model političke komunikacije između 'centra' i 'periferije'«, Politička misao, 35 (3): 187-211. 


\title{
Croatian Economy between the European Periphery and Semi-periphery: Findings from the History of Croatian High-tech Companies
}

\author{
Nikola PETROVIĆ \\ Institute for Social Research in Zagreb, Croatia \\ nikola@idi.hr
}

This paper argues that in the research on the state of the Croatian economy, emphasis should be put on historical contingency and on the geopolitical position of Croatia in order to complement prevailing explanations that accentuate cultural, inner-political or ideological factors. With the critical use of the modern world system theory and advocating eventful sociology and path-dependent analysis, the article analyses the influences of the First and Second World Wars, the Informbiro Resolution, the disappearance of the Eastern bloc and the break-up of Yugoslavia on the development of the Croatian economy. The influence of geopolitical changes on the Croatian economy and the creation of path dependencies were observed through the establishment and development of 19 Croatian hightech companies (among others; PLIVA, Končar, Željezara Sisak, Ericsson Nikola Tesla and Podravka). Twenty semi-structured interviews with the actors of the Croatian R\&D sector were conducted and official monographs, archival material and other sources dealing with these companies were analysed. The First World War and the establishment of monarchist Yugoslavia contributed significantly to the emergence of Croatian high-tech industry, as foreign capital was invested in the establishment of new companies in order to gain access to the new market that was protected by high tariffs. Preparations for the Second World War and the war itself enabled the rise of industries connected to the war economy. After the split with the Soviet Union, a specific semi-peripheral position of socialist Yugoslavia allowed Croatian companies to have closer relations with the core countries than was the case with companies from other Central European socialist countries. The disappearance of the Eastern bloc and the break-up of Yugoslavia prevented the companies analysed from using their semi-peripheral status precisely in the period of significant changes in the world economy, i.e. the emergence of techno-globalism. However, some of the high-tech companies analysed have succeeded in joining techno-global networks, among other things because of their semi-peripheral position, or were able to continue their autonomous development.

Key words: historical contingency, periphery, semi-periphery, Croatia, high-tech companies, geopolitics, techno-globalism 